This PDF is a selection from an out-of-print volume from the National Bureau of Economic Research

Volume Title: Tax Policy and the Economy, Volume 15

Volume Author/Editor: James M. Poterba, editor

Volume Publisher: MIT Press

Volume ISBN: 0-262-66122-5

Volume URL: http://www.nber.org/books/pote01-1

Publication Date: January 2001

Chapter Title: The Middle-Class Parent Penalty: Child Benefits in the U.S. Tax Code

Chapter Author: David T. Ellwood, Jeffrey B. Liebman

Chapter URL: http://www.nber.org/chapters/c10853

Chapter pages in book: (p. 1 - 40) 


\section{THE MIDDLE-CLASS PARENT PENALTY: CHILD BENEFITS IN THE U.S. TAX CODE}

\section{David T. Ellwood and Jeffrey B. Liebman}

John F. Kennedy School of Government, Harvard University, and NBER

\section{EXECUTIVE SUMMARY}

Low-income families with children receive large tax benefits from the Earned Income Tax Credit, while high-income taxpayers receive large tax benefits from dependent exemptions (whose value is greater to those in higher tax brackets). In contrast, middle-income parents receive substantially smaller tax benefits associated with children. This U-shaped pattern of benefits by income, which we call the middle-class parent penalty, not only raises issues of fairness; it also generates marginal tax rates and marriage penalties for moderate-income families that are as high or higher than those facing more well-to-do taxpayers. This paper documents how the tax benefits of children vary with income, and illustrates their effect on marginal tax rates and marriage penalties. It then examines five options for reducing or eliminating the middle-class parent penalty and the high marginal tax rates and marriage penalties it produces.

We thank Robert Cherry, Janet Holtzblatt, Michael Laracy, James Poterba, Wendell Primus, Max Sawicky, Isabel Sawhill, and participants in the NBER Children's Program meeting and an Anne E. Casey working group on working families for helpful suggestions. Ellwood is grateful to the MacArthur Foundation, and Liebman to the Russell Sage Foundation, for generous financial support. 


\section{INTRODUCTION}

Over the past decade tax benefits for families with children have increased by roughly 75 percent, due to expansions in the Earned Income Tax Credit (EITC) and the introduction of the child tax credit. Some of the tax benefits associated with children, such as the child tax credit and the dependent care tax credit, are generally non-refundable and thus benefit only those who owe taxes. Similarly, the $\$ 2,750$-per-child dependent exemption is of value only to those with positive tax liability, and its value rises with a taxpayer's marginal tax rate. By contrast, the EITC is refundable and targeted on low-income families.

The combination of the highly targeted and refundable EITC and the non-refundable credits and exemptions creates a situation where the tax benefits from children are much higher for low- and high-income parents than for middle-income parents. Middle-income parents, who earn too much to qualify for much EITC and too little to gain much benefit from the other tax-linked benefits, might be said to face a kind of middleclass parent penalty relative to their poorer and richer counterparts.

This middle-class parent penalty not only raises issues of fairness; it also generates marginal tax rates and marriage penalties for moderateincome families that are as high or higher than those facing more well-todo taxpayers. Marginal tax rates (including payroll taxes) for two-parent families can reach 50 percent or more among families with incomes near $\$ 30,000$. And for parents in the same income range the marriage penalty can, in some cases, exceed $\$ 2,000$.

This paper documents how the tax benefits from children vary with income and illustrates their effect on marginal tax rates and marriage penalties. It then examines alternative proposals for reducing or eliminating the middle-class parent penalty and the high marginal tax rates and marriage penalties it produces. Assuming that policymakers would be reluctant to cut back support for low-income working parents, any correction would necessarily involve providing more tax-based support for middle-income parents, and that would require additional revenue. But in a context where tax cuts of various sorts are being widely discussed, strategies that provide greater support for middle-income working families while improving work and marriage incentives for low- and moderate-income parents are worth examining.

\section{U.S. TAX BENEFITS FOR PARENTS}

The U.S. federal income tax code has long offered extra benefits for families and children. Some benefits are potentially available to all fami- 
lies with children so long as their income is in the appropriate range. These benefits include the EITC, the dependent exemption, and the child tax credit. Others are linked to specific expenditures such as the credit for child and dependent care expenses, flexible spending accounts for child care, the HOPE Scholarship tax credit, and education IRAs. At least one is linked to family status - the separate schedule for head-ofhousehold filers. Still others are more implicit, such as the home mortgage interest deduction, which presumably provides greater benefits to those with greater housing needs. Only the EITC and a small portion of the additional child credit for families with three or more children are refundable, so none of the others advantage people who would not owe taxes in the absence of these tax provisions.

This combination of policies makes for a complicated tax code and tax form. Adding to this complexity is the fact that different definitions of "child" are used in determining eligibility for the provisions. We begin by briefly reviewing these benefits.

\subsection{Earned Income Tax Credit}

The EITC was introduced in 1975, in part as a way to offset the payroll taxes that low-income taxpayers must pay. It is fully refundable. Over the years it has been expanded considerably. Today it is often seen as a way of ensuring that working families are not poor. Indeed, the latest increase in the EITC was designed explicitly to ensure that a family of four with one full-time minimum-wage worker would avoid poverty through a combination of earnings, food stamps, and the EITC. ${ }^{1}$ Since 1986, benefits and other program parameters have been adjusted for inflation. Children qualify a taxpayer for the EITC if they live in the taxpayer's household for at least 6 months of the year, and they must be the natural child, stepchild, adopted child, or foster child of the taxpayer, and be under 19 (or under 24 if a full-time student, or any age if the child is permanently and totally disabled).

The EITC has a phase-in, a plateau, and a phaseout. During the phasein, each dollar in earnings is matched by an EITC equal to 34 percent of earnings for a family with one child, and 40 percent for a family with two or more children. As income rises, the credit reaches its maximum of $\$ 2,312$ for a family with one child or $\$ 3,816$ for a family with two or more children in 1999. It remains at that plateau level until family income reaches $\$ 12,460$, at which point it is phased out at a rate of 15.98 percent for families with one child and 21.06 percent for families with two or more children. The effect of the EITC on marginal tax rates thus depends

1 Ellwood (1996). 
on where one is located in the income spectrum. It sharply reduces marginal tax rates in the phase-in, has no effect in the plateau range, and raises rates in the phaseout.

\subsection{Dependent Exemption}

The dependent exemption is deducted from family income before calculating taxes. In 1999 it equaled $\$ 2,750$ per dependent. Although it is now inflation-adjusted, its value relative to per capita income has shrunk from 42 percent in 1946 to roughly 10 percent in recent years. ${ }^{2}$ The exemption begins to phase out slowly $(0.8$ percent per $\$ 1,000)$, starting at roughly $\$ 190,000$ in adjusted gross income for married couples and $\$ 160,000$ for single heads of household. The dependent exemption is available for any child under 19 and any full-time student under 24 for whom the family provides over half of the support, ${ }^{3}$ regardless of how long the dependent lived in the household.

Because the exemption reduces taxable income, its value naturally increases with marginal tax rates until it begins to phase out. For someone who otherwise owes no taxes it is worthless. For those in the 15-percent bracket it is worth $\$ 413$; for those in the 28 -percent bracket it is worth $\$ 770$; for those in the 36-percent bracket, which begins at $\$ 159,000$ for a married couple, it is worth $\$ 990$ in tax savings. Unless the exemption moves a family into a lower tax bracket, it has no effect on marginal tax rates.

\subsection{Child Tax Credit}

The child tax credit was adopted in 1997. Families receive a tax credit of $\$ 500$ for each qualifying child. A qualifying child is a natural child, stepchild, adopted child, or foster child who is under 17 and for whom the family can claim a dependent exemption. The credit is not refundable for families with fewer than three children. For those with three or more children, it is refundable to the extent that the employee portion of payroll taxes exceeds the refundable portion of the EITC. The credit is phased out at a rate of $\$ 50$ per $\$ 1,000$ of income, starting at $\$ 110,000$ for married taxpayers and $\$ 75,000$ for unmarried heads of households. The benefit and limits are not indexed to inflation.

The value of the credit is equal to $\$ 500$ per child or the family's tax liability if it is less than $\$ 500$ per child (unless the family has more than three children, in which case it becomes partially refundable). Except for high-income taxpayers subject to the credit's phaseout, it does not alter

2 McIntyre and Steuerle (1996). Whittington, Alm, and Peters (1990) present evidence that U.S. fertility rates have responded to the level of the dependent exemption.

${ }^{3}$ It is also available for others whose gross income is below the exemption amount. 
marginal tax rates at all (unless it pulls people into a range where they owe no taxes).

\subsection{Dependent Care Credit}

The dependent care tax credit originated in 1954 and has gone through many changes. Currently it provides a credit of up to 30 percent for allowable dependent care expenses for children under 13. Allowable expenses are limited to $\$ 2,400$ for families with one dependent and $\$ 4,800$ for two or more. Benefits are reduced by half a percentage point for each dollar of income above $\$ 10,000$, but never fall below 20 percent of allowable costs. ${ }^{4}$ The credit is not refundable. Limits are not indexed to inflation.

The benefit of this credit generally will be 20 percent of child care expenses up to a maximum benefit of $\$ 960$ for two children. It benefits only those with positive tax liabilities. It has no effect on marginal tax rates unless people are moved into a zero tax range.

\subsection{Employer-Provided Dependent Care}

The value of certain employer-paid dependent care expenses of up to $\$ 5,000$ are also excludable from income. This includes both actual care provided directly in the workplace, which is rare, and flexible spending accounts, which are much more common. ${ }^{5}$ Under a flexible spending account, employees have the option of placing up to $\$ 5,000$ in pre-tax income in an employer-sponsored account. This money is then disbursed by the employer to reimburse for qualifying child care expenses paid by the employee. Such accounts are uncommon in small firms, but in medium to large firms they are often part of a flexible set of benefits. According to the 1998 Green Book, slightly over one-third of full-time employees in medium- to large-size establishments were eligible for these accounts in 1991.6 Expenses covered by flexible spending accounts reduce dollar for dollar the amount of expenses eligible for the dependent care tax credit. This benefit does not phase out at higher incomes.

Like any deduction, the value of this provision depends on the tax rate of the family. It is worth nothing to those with no income, and up to

\footnotetext{
${ }^{4}$ Because the dependent care credit phases out so early, and given the other nonrefundable credits like the child tax credit, under the current tax rules, the net gain of the dependent care credit rarely is much greater than the minimum 20 percent for taxpayers
with children.
}

${ }^{5}$ Committee on Ways and Means (1998, p. 878).

${ }^{6}$ Ibid., p. 878.

${ }^{7}$ Gentry and Hagy (1996) discuss the distribution of child-care tax benefits. 
$\$ 1,800$ for those in the 36-percent tax bracket. It alters marginal rates only if taxpayers are moved to a lower bracket.

For low-income households, the dependent care tax credit is usually more valuable than the flexible spending account. A family in the 15-percent tax bracket with two children is eligible for a tax credit of between 20 and 30 percent on up to $\$ 4,800$ of dependent care expenses; the credit is therefore potentially worth between $\$ 960$ and $\$ 1,440$. In contrast, the opportunity to exclude $\$ 5,000$ in expenses through a flexible spending account is worth only $\$ 750$ to a taxpayer in the 15-percent tax bracket. For a taxpayer in the 28-percent bracket the relative attractiveness of the two policies is reversed. The dependent care tax credit is worth 20 percent of the first $\$ 4,800$ of expenses, or $\$ 960$, while the opportunity to exclude $\$ 5,000$ of expenses from income is worth $\$ 1,400$.

\subsection{Education Benefits}

There are a number of education-related tax benefits. In 1997, the HOPE credits were established. They provide a 100-percent credit for the first $\$ 1,000$ in qualifying educational expenses and $50 \%$ for the next $\$ 1,000$. They are available for expenses only in the first two years of postsecondary education. After 2001, the credit will be indexed to inflation. ${ }^{8}$

The lifetime learning credit allows a 20-percent credit of up to $\$ 5,000$ in qualifying educational expenses. There is a lifetime limit on the credit of $\$ 2,000$. There is no limit on age or relationship. Both the HOPE and lifetime learning credit are phased out over the range of $\$ 80,000$ to $\$ 100,000$ of income for joint filers and $\$ 40,000$ to $\$ 50,000$ for single filers.

Parents and grandparents can place money in an education IRA for children. Neither the contributions nor the disbursements are taxed, so long as the money is used for a qualifying educational institution. The maximum contribution is $\$ 500$ per year. The contribution allowance is phased out starting at $\$ 150,000$ for joint returns and $\$ 95,000$ for others. Qualified state tuition savings plans are also tax-exempt.

\subsection{Head-of-Household Filing Status}

There are three primary filing statuses: married filing jointly, head of household, and single. As is well known, tax schedules and deductions are such that for a given level of taxable income, taxes are lowest for joint filers, higher for heads of households, and highest for single persons,

${ }^{8}$ Dynarski (2000) finds that Georgia's HOPE Scholarship, the inspiration for the new federal Hope Scholarship, increased the college attendance rate of middle- and highincome youth, but widened the college attendance gap between blacks and whites and between those from low- and high-income families. 
but the tax brackets for couples are less than twice those of singles. ${ }^{9}$ Marriage puts people into joint filing status, so the benefits or costs of filing joint returns are not tied directly to the presence of children per se. But in the case of head-of-household filers, it is often the presence of children that puts them into the filing category. Whether the parent is divorced or never married, he or she would be in a less favorable tax status without children.

In some cases, however, eligibility for the head-of-household status is not dependent on the presence of children. Some heads of households with children are also living with other relatives or grown children, so at the margin, the children do not create the benefit. Moreover, one might argue that the lower tax rates of one-earner joint filers (relative to filing separate single returns) similarly reflect a recognition that married couples will generally have children and need to set up a household, even though, technically, joint filing status is tied to marriage, not parenting.

Still, if we ask the simple question "How much benefit does being able to file as a head of household yield?" the answer is sizable. In the case of a single parent, the head-of-household status allows her $\$ 2,050$ more in the standard deduction and better tax brackets than if she filed as a single adult. The benefits of being a head-of-household filer versus a single filer rise with income, from $\$ 308$ for someone with an income of $\$ 20,000$ to $\$ 3,500$ and more for the small group of single parents with incomes above $\$ 150,000$ annually.

\subsection{Other Tax Benefits}

The mortgage interest deduction also offers some benefits for children. Families with children may spend more on housing, thus gaining greater tax benefits. The deductibility of employer-paid health insurance premiums and excess health expenses, the linkage between many state taxes and federal provisions, and even the deductibility of state and local taxes all influence the benefits associated with children. Nearly all of these typically grow with income, largely because the benefits to deductions are greatest when marginal tax rates are highest.

\subsection{The Budgetary Cost of Child Benefits}

Table 1 shows the relative magnitude of the main child-related tax provisions in terms of the revenue loss for the federal income tax. ${ }^{10}$ Lost

${ }^{9}$ In two-earner households, the taxes of joint filers may be higher or lower than they would be if persons with the same income had filed separately-hence this is one source of
marriage penalties and rewards.

10 The cost of tax expenditures in these calculations is only the cost in federal income taxes.

Some of these provisions reduce a taxpayer's payroll taxes as well. 
TABLE 1

Budgetary Cost of Selected Tax Benefits for Families with Children, FY 2001

\begin{tabular}{lc}
\hline Benefit type & Cost (\$billions) \\
\hline Dependent exemption & 34.0 \\
Earned Income Tax Credit & 30.6 \\
Child tax credit & 20.0 \\
Head-of-household filing status & 3.9 \\
Dependent care credit & 2.4 \\
Employer-provided child care & $\underline{0.7}$ \\
Total & $\mathbf{9 1 . 6}$ \\
\hline
\end{tabular}

Sources: Dependent exemption and head-of-household filing status are based on authors' calculations from 1995 SOI tax file, inflated to 2001 dollars. The remaining numbers are from Table 5-1 of Office of Management and Budget $(2000)$. Tax expenditures reflect effect on federal income tax revenue only (not OASDHI).

revenue from exemptions for dependent children will total around $\$ 34$ billion in 2001, more than any other child-associated tax benefit. The EITC is expected to cost $\$ 31$ billion in FY 2001, and the child credit $\$ 20$ billion. The other provisions are much smaller. Allowing taxpayers to file with the head-of-household filing status instead of filing as single costs $\$ 4$ billion dollars. The total cost of the dependent care credit and the tax expenditure for employer-provided child care is only $\$ 3$ billion.

\section{THE CUMULATIVE EFFECT OF THE VARIOUS CHILD TAX BENEFITS}

The rather obvious insight from this discussion is that the tax code provides relatively sizable tax benefits to low- and high-income families with children-the former through the EITC, the latter through tax benefits that tend to rise with income, at least to a point. For the group in the middle income range, tax benefits are much smaller. Yet this feature has been emphasized by only a few authors. Eugene Steuerle has focused particular attention on child tax-code provisions, often adding the complication that the interaction of the tax code with provisions of the transfer system creates skewed and complex incentives. ${ }^{11}$ Perhaps the most important work that focuses on the U-shaped benefit pattern has been done by Robert Cherry (1998) and more recently as part of significant

11 See for example Steuerle (1990), Steuerle and Juffras (1990), and McIntyre and Steuerle (1996). 


\section{TABLE 2 \\ Tax Benefits Associated with Having Two Children: Married Couple for Tax Year 1999}

\begin{tabular}{lrrrr} 
& \multicolumn{4}{c}{ Benefit at Family Income (\$) } \\
\cline { 2 - 5 } Benefit type & 12,000 & 20,000 & 35,000 & 75,000 \\
\hline Earned Income Tax Credit & 3,816 & 2,228 & 0 & 0 \\
Dependent child exemptions & 0 & 825 & 825 & 1,540 \\
Child tax credit & 0 & 270 & 1,000 & 1,000 \\
Dependent Care Tax Credit & 0 & 0 & $\frac{350}{750}$ \\
Total & 3,816 & $\mathbf{3 , 3 3 2}$ & $\mathbf{2 , 1 7 5}$ & $\underline{3,290}$ \\
\hline
\end{tabular}
(a) Assumes couple spends 5 percent of income on allowable child care and both children are depen-
dent children under 17 .

new work with Max Sawicky. ${ }^{12}$ In addition, these authors have recently proposed an expansion to the EITC somewhat similar to an option below. This paper extends this work, illustrating in detail the actual incidence of the various child tax benefits, examining impacts of a range of reform proposals, and estimating costs and effects from actual tax data.

The current situation can be illustrated with the following example. Suppose that a married couple has two dependent children living at home and that the couple pays 5 percent of its income in allowable child care expenses. Table 2 illustrates the couple's net tax benefits from having children from the four most important child-linked benefits. In decomposing the total tax benefits from individual provisions, one must order the benefits. In the situation where the combined value of various non-refundable child benefits exceeds the total tax liability of the family without them, taxes fall to zero, and there is ambiguity as to which benefit to treat as having reduced the liability first. In such a case, we attribute benefits first to the dependent exemption and then to the child tax credit (since these two tax benefits are available for nearly every child), and finally to the dependent-care tax credit.

The treatment of the dependent-care credit is ambiguous, since these benefits depend on expenditures. It seems unlikely that a family with $\$ 30,000$ would spend the $\$ 4,800$ necessary to gain the full benefits. Thus for this example we have assumed that families' child care expenses grow with income. We assume a expenditure equal to 5 percent of income; families with two children do not get the full benefit of the credit until their spending reaches $\$ 4,800$ ( $\$ 96,000$ in income in this example). Different assumptions would yield different results from this credit.

12 Cherry and Sawicky (2000). 
Families with two children and $\$ 12,000$ of income qualify for the full EITC of $\$ 3,816$. A family with $\$ 20,000$ has a reduced EITC, and gets only partial benefits from the other child tax provisions, because the family would owe relatively little in taxes, so its benefits total $\$ 3,332$. A couple with $\$ 35,000$ receives even less. That couple gets no EITC, and even with the full benefit of the tax provisions, the total tax benefits from children fall to under $\$ 2,200$. Then for families with incomes of $\$ 75,000$ the benefit rises again to $\$ 3,290$, since the dependent exemptions are worth more to a family in the 28-percent bracket than to one in the 15-percent bracket.

These figures would be even more dramatic if the higher-income family could get its child care paid through an employer-sponsored flexible spending account-that would add $\$ 300$. Other tax benefits cited above, such as higher-education credits, are also more likely to benefit the wellto-do, not only because they are more likely to be eligible for them, but also because they are often in the form of a deduction whose value is greater for those in higher brackets. Several authors have shown that children from higher-income families are far more likely to go on to postsecondary schooling than low-income families are. ${ }^{13}$

One can see how these benefits play out over a much wider range of incomes and for several different family settings in Figures 1 to 5 . Figures 1 to 3 are for married couples with different numbers of children. Figure 4 is for a head-of-household filer with two children where we do not include the potential value of the head-of-household status, because it is an ambiguous child benefit. Then in Figure 5 we include the value of the head-of-household filing status on the assumption that the person would have filed as a single taxpayer in the absence of the two children. In most of our subsequent work we do not include the value of this head-of-household designation as a child benefit.

We will concentrate on Figure 2, the tax benefits associated with two children for a married couple. Married taxpayers filing joint returns account for 64 percent of all tax returns claiming child tax benefits and claim almost 70 percent of all dependent child exemptions. ${ }^{14}$ The total tax benefit associated with children is decomposed into its four main components for a married couple with two children. The EITC is the main benefit for taxpayers with incomes below $\$ 25,000$ or so. The value of the dependent exemption rises from $\$ 825$ in the 15 -percent tax bracket to $\$ 1,540$ in the 28-percent bracket, and $\$ 1,705$ in the 31-percent bracket.

${ }^{13}$ See for example Ellwood and Kane (2000) and Cameron and Heckman (1999).

14 Among lower-income taxpayers (those with AGI below $\$ 40,000$ ), married taxpayers filing joint returns represent only 44 percent of taxpayers claiming children, though they claim 50 percent of the children. Head-of-household filers represent the bulk of the balance. 


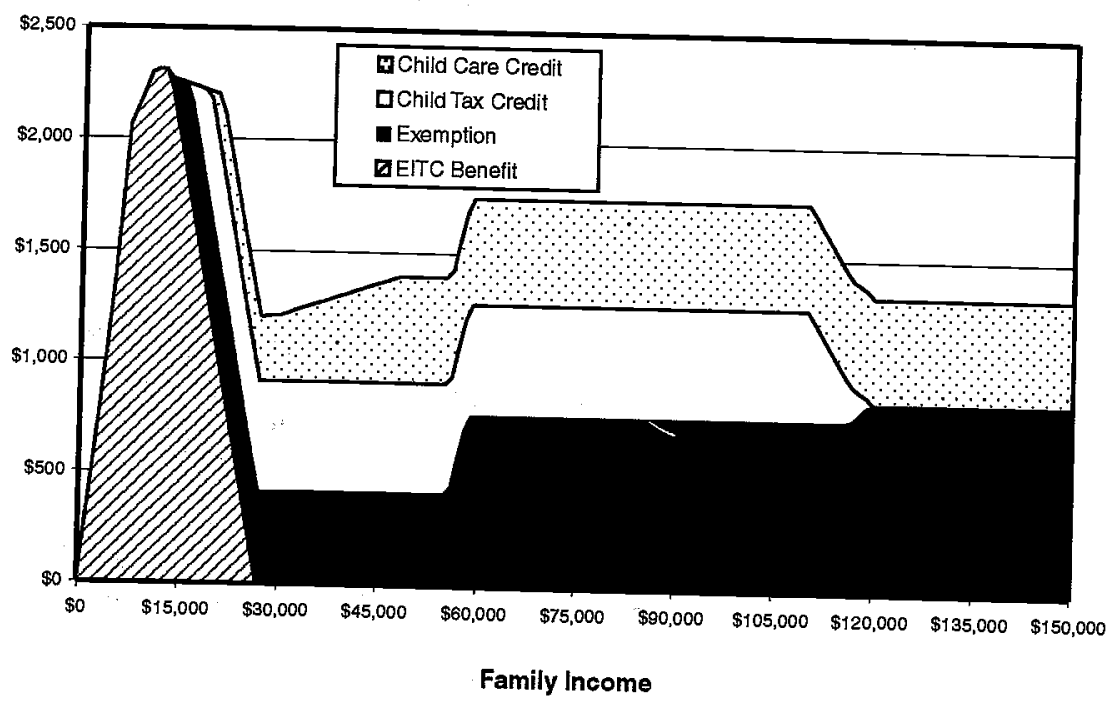

FIGURE 1. 1999 Tax Benefits Associated with Having One ChildMarried Couples under Current Law, Assuming Child Care Expenses of 5 Percent of Income

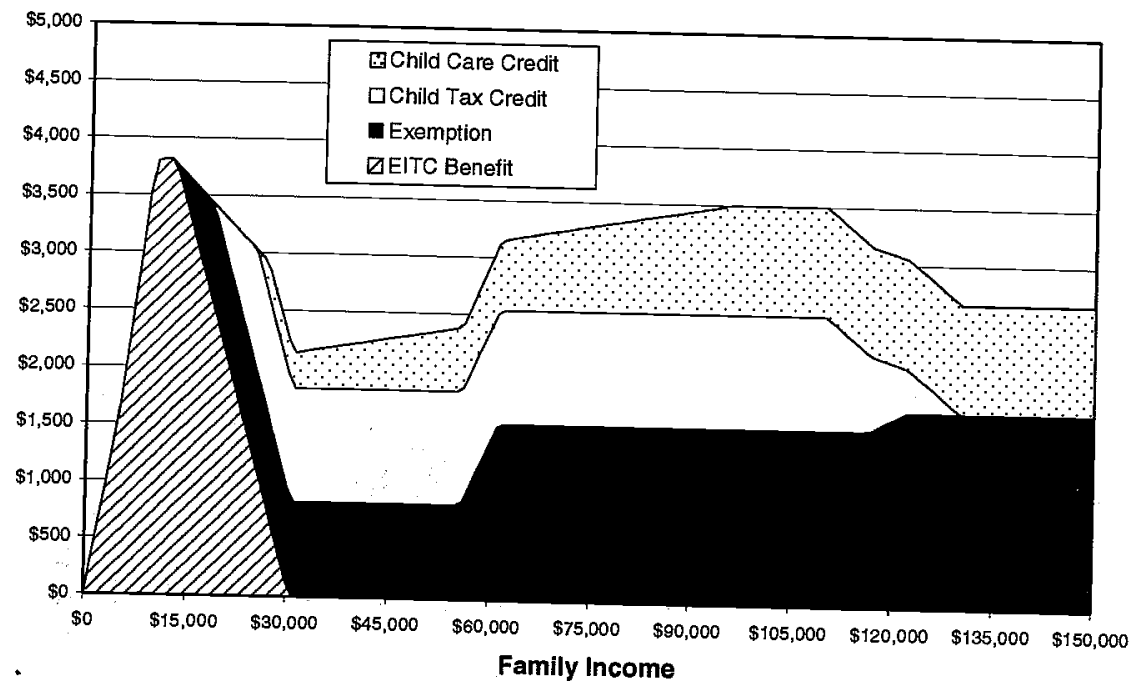

FIGURE 2. 1999 Tax Benefits Associated with Having Two ChildrenMarried Couples under Current Law, Assuming Child Care Expense of
5 Percent of Income 


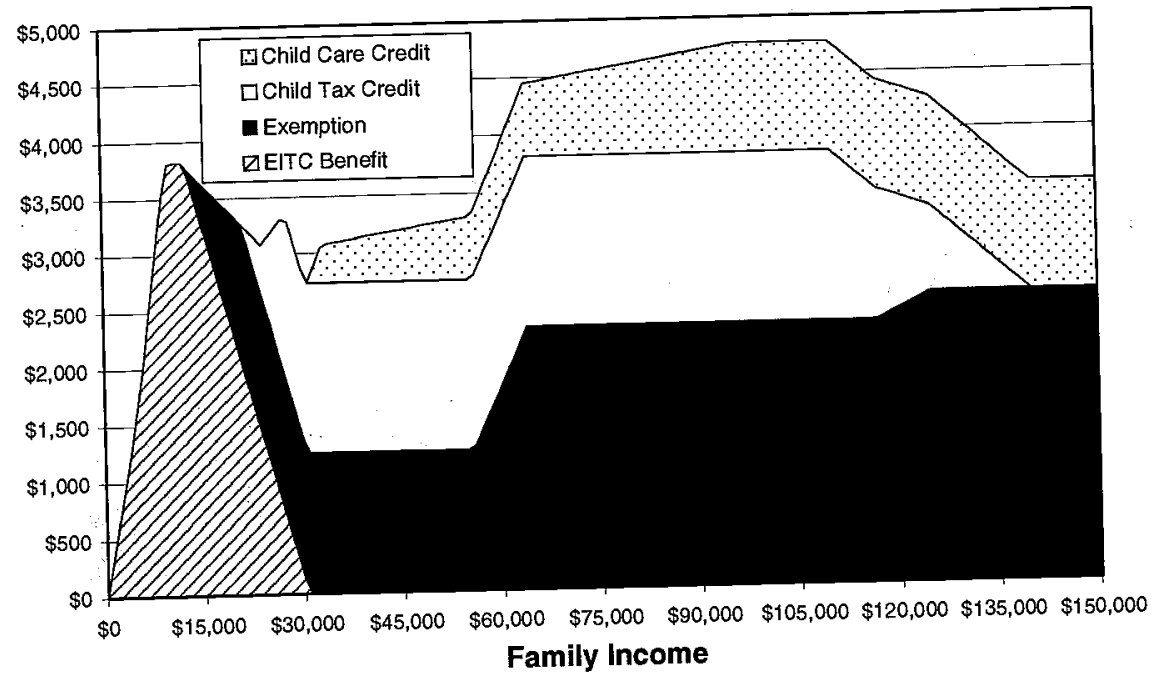

FIGURE 3. 1999 Tax Benefits Associated with Having Three Children-Married Couples under Current Law, Assuming Child Care Expense of 5 Percent of Income

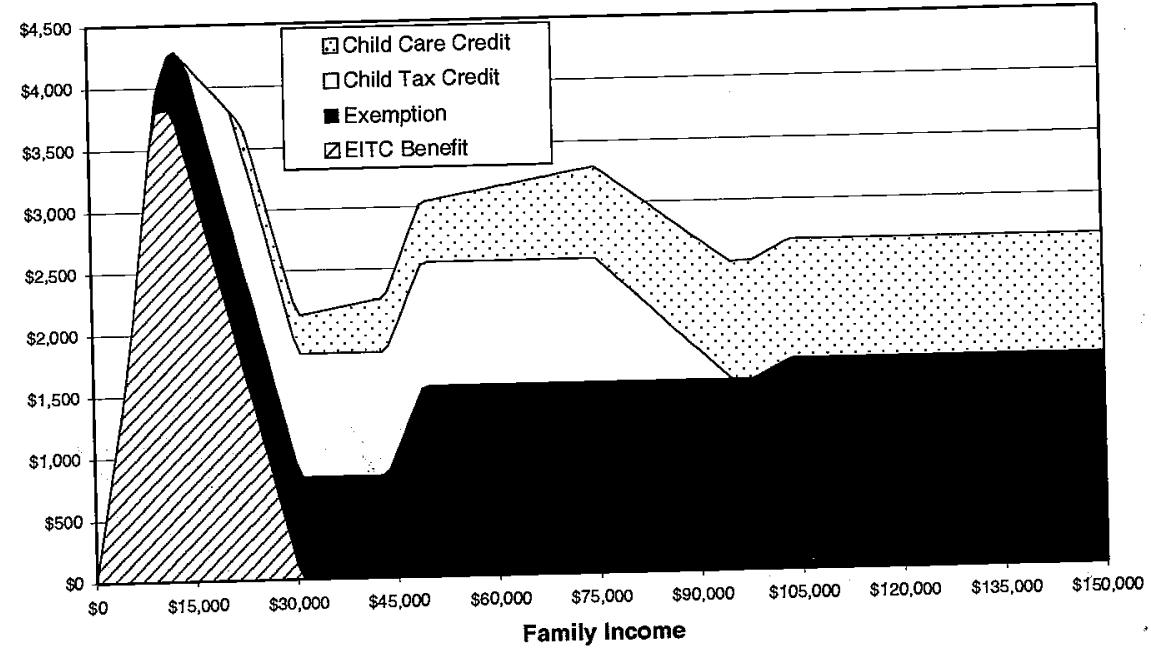

FIGURE 4. Tax Benefits Associated with Having Two ChildrenUnmarried Adult under Current Law, Ignoring Change in Filing Status, and Assuming Child Care Expense of 5 Percent of Income 


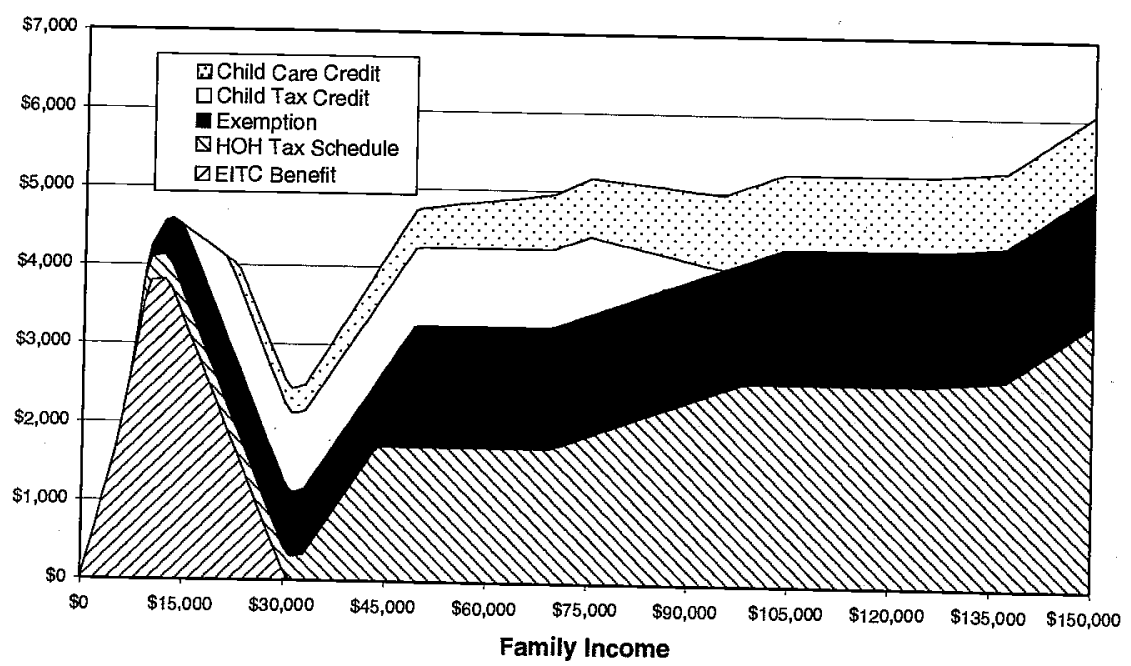

FIGURE 5. 1999 Tax Benefits Associated with Having Two ChildrenUnmarried Adult under Current Law, Including Value of Head-ofHousehold Filing Status and Assuming Child Care Expenses of 5 Percent of Income

The value of the child tax credit is constant at $\$ 1,000$ for this family once tax liabilities are positive. However, the child credit is phased out for households with income above $\$ 110,000$ ( $\$ 75,000$ for single heads), and therefore the total tax benefits to children fall above this income level. ${ }^{15}$

In all of the figures, the largest benefits tend to be concentrated in the $\$ 10,000$-to- $\$ 12,000$ income range and the $\$ 75,000-$ to- $\$ 100,000$ range. At times the tax benefits rise and fall rapidly. Figure 3 , for families with three children, is particularly striking. The sudden blip at roughly $\$ 30,000$ is caused by the quasi-refundable nature of the child tax credit (refundable up to the point where the credit plus the EITC equals payroll taxes) for families with three or more children.

The figures indicate that the pattern varies widely across families, and even these comparatively simple plots mask considerably greater complexity and variation in actual practice. Because of the significant number of contingent benefits-those available only to people with particular costs such as higher education or child care-child benefits vary considerably even for people with the same incomes. Moreover, the definition of a qualifying child varies considerably across programs-for

15 A phaseout of dependent exemptions occurs beyond the income level shown in this figure (between $\$ 189,950$ and $\$ 312,450$ for married couples). 
example, the EITC is available only to those for whom a child lived in the home for more than 6 months, while the dependent exemption is based on a dependency test, independent of residence.

\section{THE OBSERVED INCIDENCE OF CHILD BENEFITS}

In order to examine the actual effect of these provisions and to gain a greater sense of what the distribution of child tax benefits looks like in practice, we analyzed child tax benefits using a sample of tax returns. Specifically, we used the IRS Statistics of Income 1995 Public Use Tax File. This data set is representative of all individual income tax returns filed for tax year 1995. Because we want our results to be representative of more recent tax rules, we aged the data to better represent 1999 conditions by increasing all income components at the growth rate of personal income between 1995 and 1999. Then we applied 1999 tax rules to the data.

One detail of our methodology deserves further discussion. The child credit was not in place in 1995, so we do not observe the number of children a taxpayer is entitled to claim for the child credit. We do have information on the number of children claimed for the dependent exemption and the EITC. But only children under age 17 can be claimed for the child tax credit, whereas children up to age 24 who are full-time students can qualify for the dependent exemption. ${ }^{16}$ In our marginal-tax-rate simulations, we assume that a taxpayer can claim the child credit for any dependent child, though this clearly will lead to us assigning the credit for some dependent children who are 17 and older. However, we adjust our cost estimates to ensure that the right number of returns receive the child credit. We do not examine the education tax credits, because they did not exist in 1995; nor do we examine the credit for employerprovided child care, because we cannot observe it in our data. ${ }^{17}$

Figure 6 shows the distribution of tax returns with children by income (kernel density estimates). The top panel shows the distribution of the 27.0 million married tax returns claiming children. The bottom panel shows the distribution of the 13.6 million head-of-household returns claiming children (another 2 million returns claim children using other filing statuses). These figures show that while the bulk of head-ofhousehold taxpayers with children have adjusted gross incomes be-

16 Even older children with earnings below $\$ 2750$ in 1999 can be claimed as dependent children, though this is a very small group.

17 Mitrusi and Poterba (2000) construct a similar model that includes imputations of education tax credits. 
tween $\$ 10,000$ and $\$ 30,000$, married taxpayers with children are distributed across a much wider income range, with substantial numbers of taxpayers having incomes above $\$ 50,000$ (results not shown indicate that the average number of children per tax return does not vary much with income within a filing status). The average head-of-household tax return has roughly 1.53 children, and the average married tax return has 1.94 children).

Figure 7 depicts the average tax benefit to claiming children by income, and decomposes this average into the four main tax provisions. Thus, this figure is analogous to Figures 1 to 5 . But instead of showing the theoretical tax benefits for a given household, they show the actual
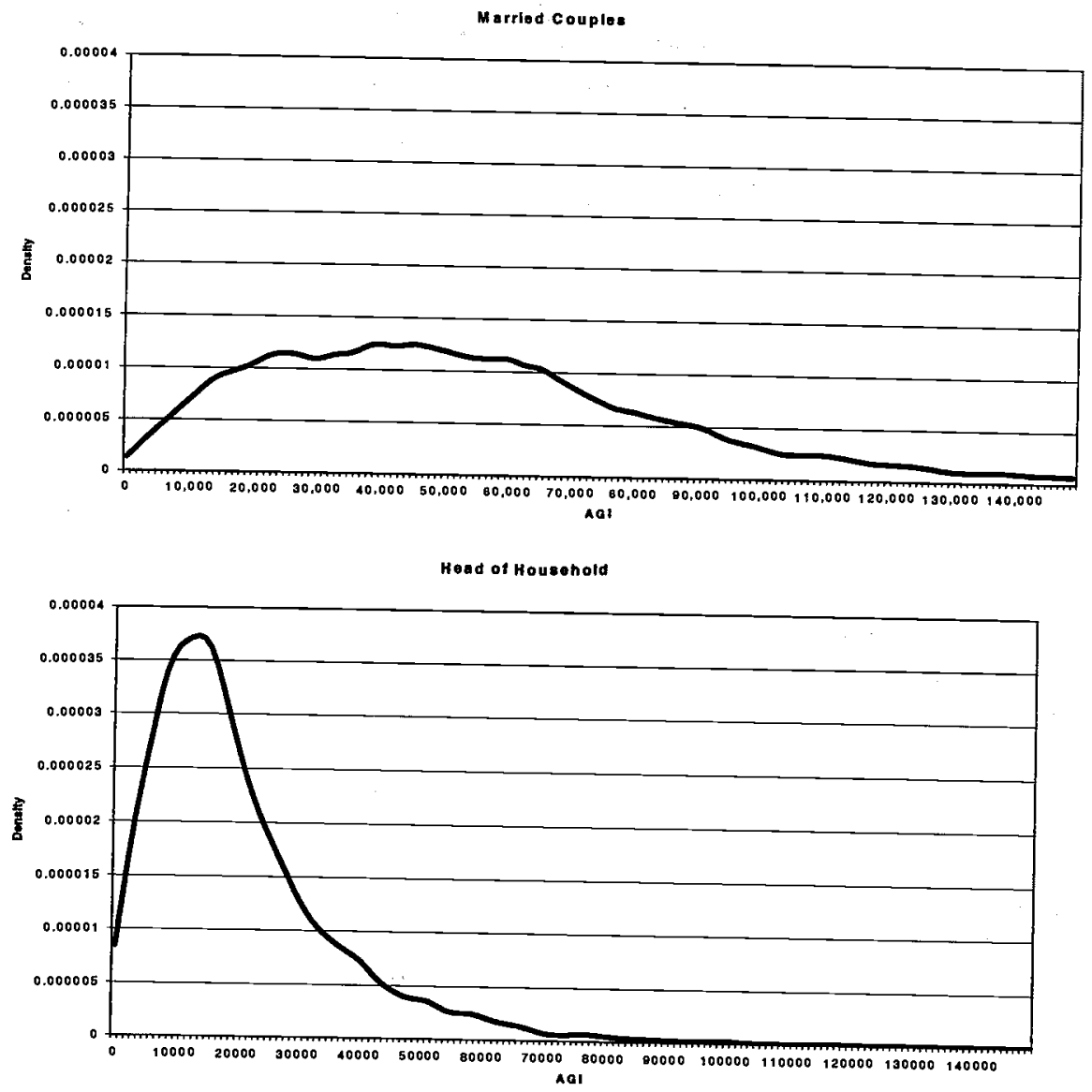

FIGURE 6. Distribution of Tax Returns with Children by AGI 


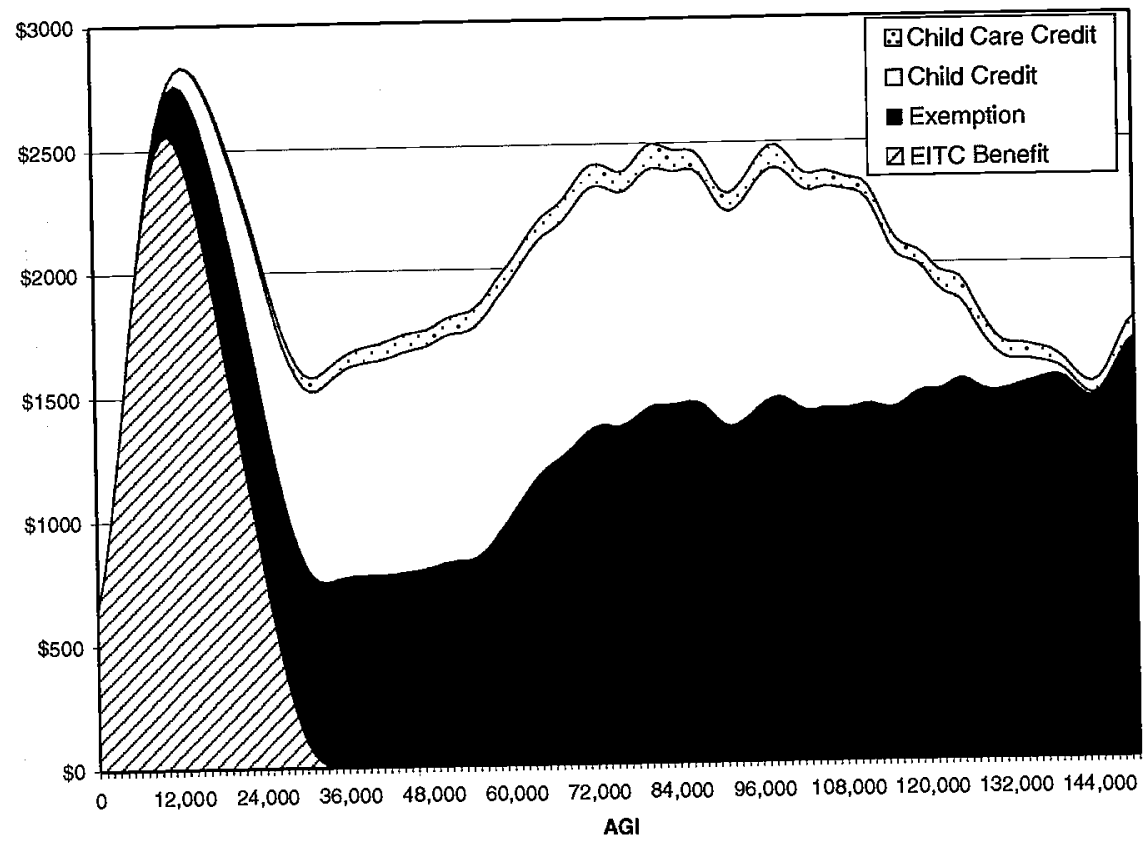

FIGURE 7. Average Tax Benefits from Children by AGI, All Taxpayers with Children

average benefit received for families at different levels of adjusted gross income (AGI). The estimates in the figure average across all of the tax returns at a given level of AGI-households that will receive different benefits because they have different numbers of children, different tax schedules due to different filing statuses, differences in itemized deductions, etc. ${ }^{18}$ The actual distribution is quite similar to the theoretical distribution. Taxpayers with around $\$ 15,000$ of income have the highest benefits, due to the EITC. Benefits then fall for taxpayers in the 15percent income tax bracket and rise for higher-income taxpayers. Note that in calculating these figures we did not include the potential value of the head-of-household status.

Figure 8 depicts the distribution of total dollars from these four provisions by AGI, essentially weighting the average tax benefits in the previous figure by the number of tax returns at each level of AGI. Although high-income taxpayers get large average benefits, this figure shows that relatively few dollars are spent on them, since there are relatively few taxpayers with high incomes. In fact, because of their large numbers,

18 The figures depict kernel regressions of tax benefits on AGI. 
Distribution of Dollars from Child Benefits

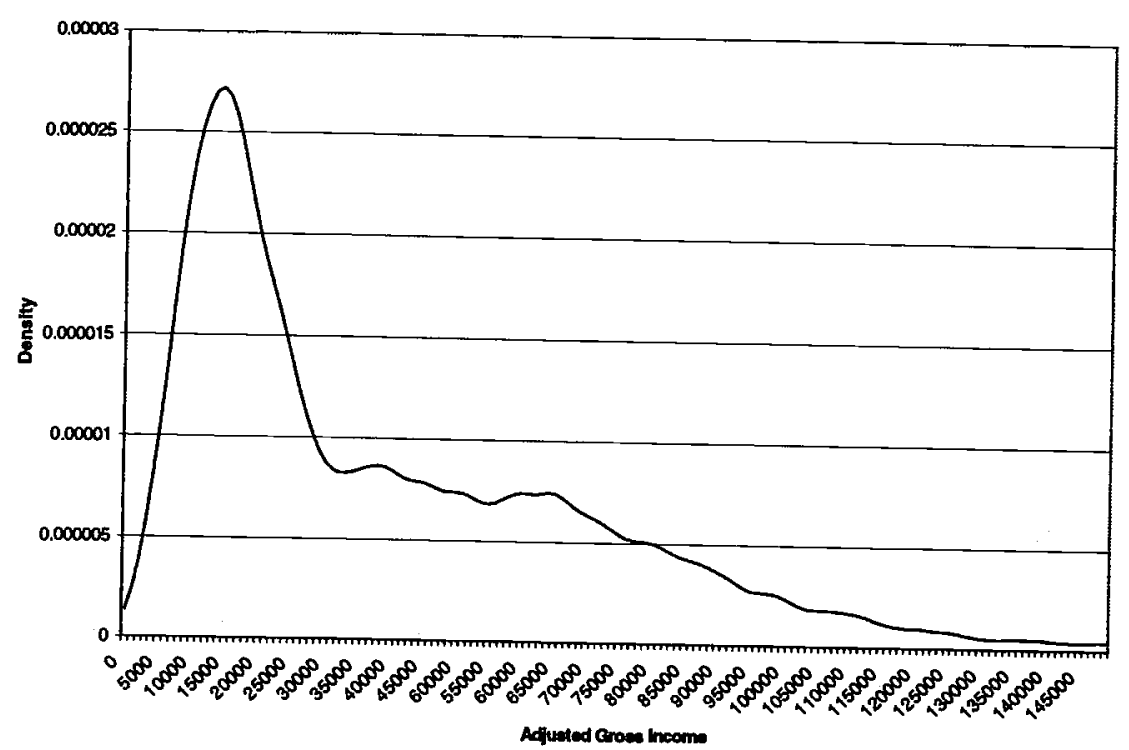

\section{FIGURE 8. Distribution of Dollars Spent on Child Benefits by AGI}

more total dollars are spent on the middle-income families who face the parent penalty than on higher-income families.

Generally these benefits look much like what one might predict based on the figures shown earlier. One interesting fact is that at all income levels, dependent-care credits are quite small on average, though they are undoubtedly highly variable. Thus for the remaining discussion in this paper, we will concentrate on the child benefits of the EITC, the dependent-child exemption, and the child credit, and ignore any dependent-care or other child-related tax benefits.

\section{THE EFFECT OF CHILD TAX BENEFITS ON TAX RATES AND WORK INCENTIVES}

Considerable attention has been devoted to discussions of marginal tax rates and marriage penalties in recent years. Most of the attention has been directed at the traditional features of the tax code: notably the brackets, the tax rates, and the differential treatment of married and single people. Yet the child tax benefits sharply influence marginal rates and marriage incentives, and for lower income tax filers, their importance is quite sizable. 


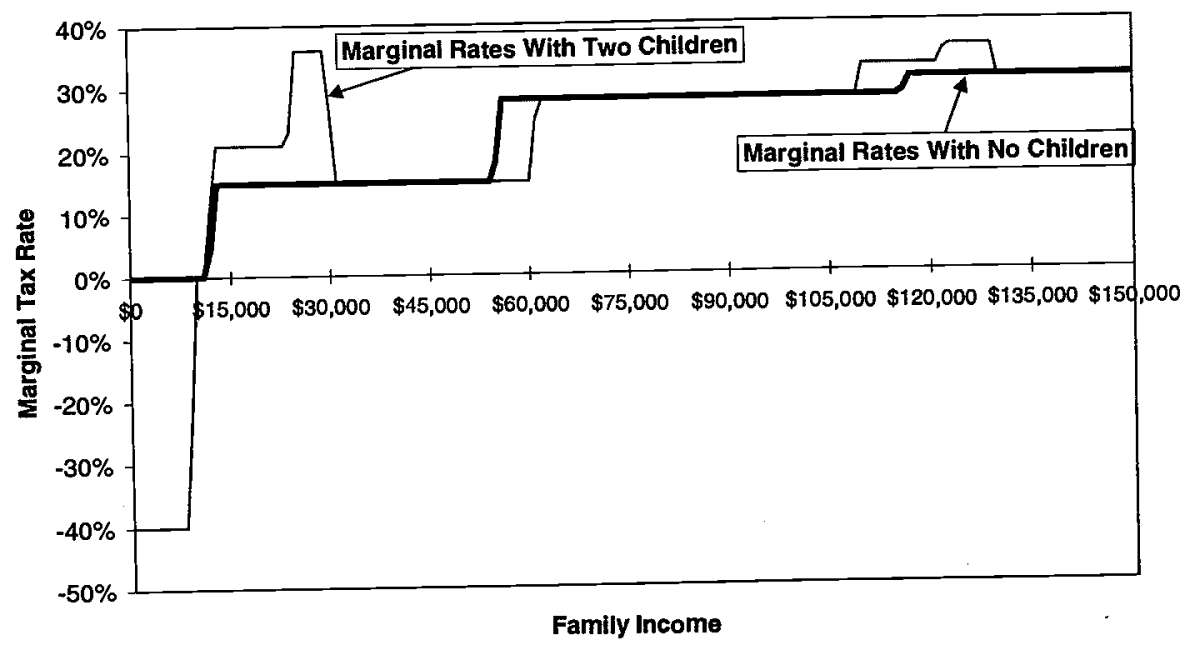

FIGURE 9. Marginal Income Tax Rate for Married Couple with Two Children under Current Law As Compared to a Couple with No Children (No Allowable Child Care Expenses)

Figure 9 compares marginal personal income tax rates for a married couple with two children and a married couple without children. ${ }^{19}$ The child-linked tax benefits clearly complicate the comparatively simple picture of incentives facing childless couples. Any time child benefits are rising with income they lower marginal rates, and vice versa. For the lowest-income taxpayers, the EITC has the effect of making marginal income tax rates highly negative, thus creating strong work incentives. For a family with two children the EITC provides a 40-percent credit over a range in which other federal income taxes are zero, effectively raising pay by 40 percent. Later, after income gets to about $\$ 12,500$, the credit is phased out at a 21-percent rate. During part of the phaseout, the family faces no ordinary taxes (as the dependent exemption and child credit offset any taxes), so the tax rate is 21 percent. Then one reaches a point where all the exemptions and credits have been exhausted, but the EITC is still phasing out, so the marginal income tax rate jumps to 36 percent (21-percent phaseout plus 15-percent tax rate). Above the EITC phaseout range, rates largely mirror the regular tax rates until the child credit begins phasing out at $\$ 110,000$, pushing up marginal rates again.

Table 3 shows the actual distribution of marginal federal income tax rates for taxpayers with children at various income levels, using the IRS

19 This figure is drawn assuming that taxpayers take the standard deduction and that all income is earned income. 


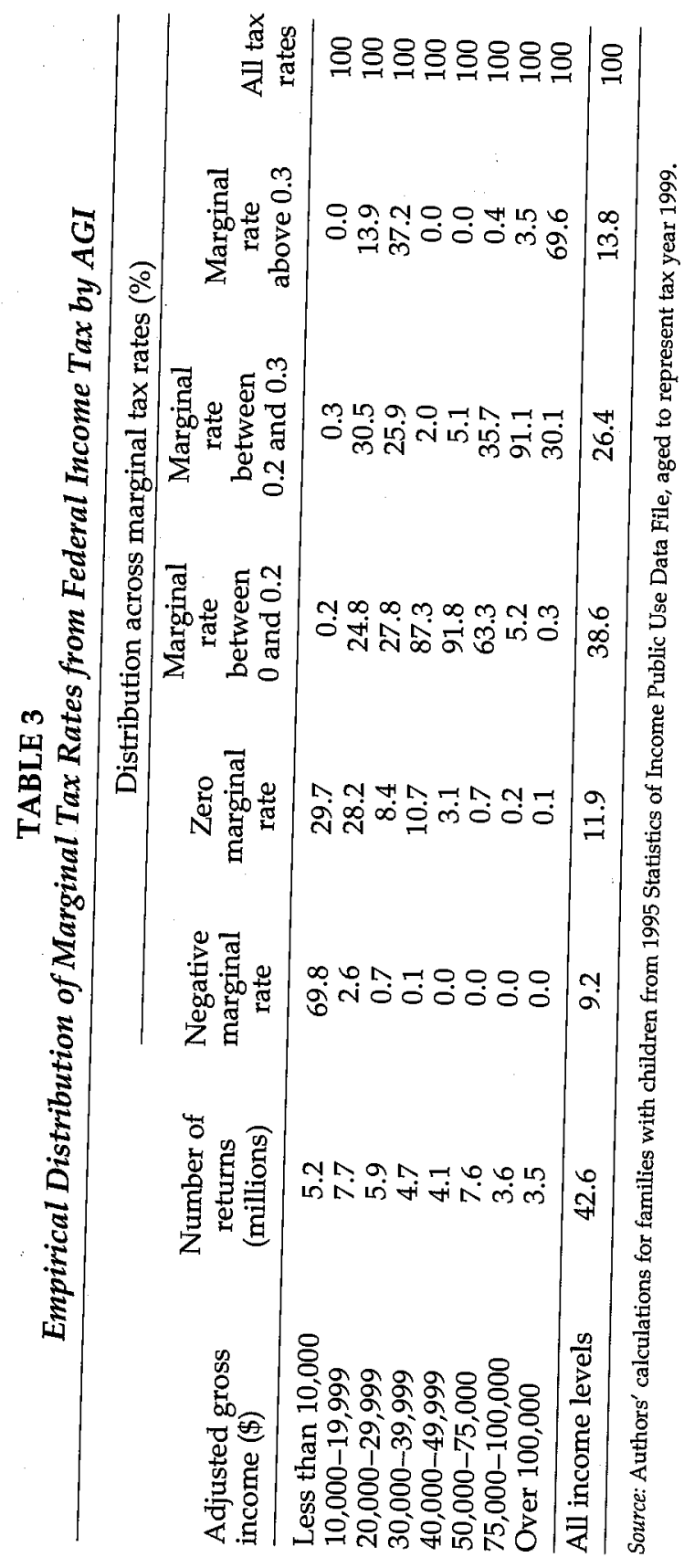


Statistics of Income 1995 Public Use Tax File and aged as described earlier. Seventy percent of taxpayers with AGI below $\$ 10,000$ face negative marginal tax rates because of the phase-in of the EITC, while nearly all of the remaining 30 percent face zero marginal tax rates. At incomes between $\$ 10,000$ and $\$ 20,000$, a substantial number of taxpayers face high marginal rates. Thirty-one percent face marginal tax rates between 20 percent and 30 percent (taxpayers who are in the phaseout region of the EITC but owe no federal income tax), and 14 percent face marginal income tax rates above 30 percent (taxpayers who are in the phaseout region of the EITC and owe federal income tax).

Between $\$ 20,000$ and $\$ 30,000,37$ percent face marginal tax rates above 30 percent. In contrast, essentially no taxpayers with incomes between $\$ 30,000$ and $\$ 75,000$ face marginal tax rates above 30 percent. It is not until incomes exceed $\$ 100,000$ that a substantial share of taxpayers face marginal tax rates as high as those faced by taxpayers between $\$ 15,000$ and $\$ 30,000$. Indeed, of all taxpayers with children facing marginal tax rates above 30 percent, 55 percent have incomes below $\$ 30,000$.

Note that these rates are not the full effective tax rates on earnings. First, they do not include payroll taxes of 7.65 percent for employees and the same for employers. If we add the full 15.3-percent taxes on top of these rates, marginal tax rates exceed 50 percent for couples just below $\$ 30,000$. Nor do they include state taxes. And finally, many low-income families also qualify for food stamps, temporary assistance for needy families (TANF), government-provided medical insurance, and the like. As earnings rise, such benefits fall, effectively pushing up marginal tax rates still further.

A major thrust of policy in recent years has been to reduce the transfers to low-income families without workers and expand supports for working ones. Dramatic expansions in the EITC, changes in welfare policy, and expanded supports for low-income working families have all served to radically alter incentives facing low-income families..$^{20}$ Ellwood (2000) shows that a woman with two children who left welfare for fulltime work at a minimum-wage job used to face an effective tax on her earnings of nearly 80 percent in 1986 when one took account of taxes and lost benefits. By 1999, mostly as a result of the expanded EITC, the tax rate was below 30 percent.

Numerous authors including Eissa and Liebman (1996), Blank, Card, and Robbins (2000), Meyer and Rosenbaum (1999), and Ellwood (2000), have found large growth in the labor supply of single parents over this

20 See for example, Eissa and Hoynes (1999b) and Blank, Card, and Robbins (2000). 
period, and all show that a significant share of the growth in work by single mothers can be traced to expansions in the EITC.

On the other hand, as the earlier figure would suggest, tax rates went in the other direction in families where income was already at a modest level. So, for a married mother whose husband earned $\$ 15,000$, the effective tax rate for taking a full-time job rose from 53 to 66 percent between 1986 and 1999. Somewhat less work has been done on the changing labor supply patterns of low- to moderate-income married women, but both Eissa and Hoynes (1999a) and Ellwood (2000) find that this rise in tax rates reduced the labor supply of low-income married women. ${ }^{21}$ There is still less work on whether the high marginal tax rates in this range influence the earnings of first earners. Presumably both single parents and persons in one-worker households could be induced to limit hours or earnings as a result of the high marginal rates, though the evidence so far does not find much effect. ${ }^{22}$ Thus there is a significant and growing body of evidence that the incentives created by child tax benefits do influence the behavior of at least some workers.

\section{THE EFFECT OF THE CHILD TAX BENEFITS ON MARRIAGE PENALTIES AND REWARDS}

Recently policymakers also have become occupied with the marriage penalties found in the federal tax structure. In political and even many academic discussions, the origins of such penalties are usually traced to the features of our tax system that provide for different standard deductions and tax schedules depending on a taxpayer's filing status. The standard deduction for a married couple can penalize marriage among two-earner couples because the joint deduction is less than twice the deduction for single individuals. In addition, the tax brackets for joint filers are wider than for a single individual, but not twice as wide. As a result, couples where only one person has earnings generally benefit from joint filing status, but those with two earners with nearly equal incomes are disadvantaged. These issues are now widely understood and heavily discussed in tax policy. ${ }^{23}$

Less widely understood is the fact that the child tax benefits have important implications for marriage penalties among couples with chil-

2I The reduction in labor supply by married women in response to the EITC does not represent deadweight loss if it is the income effect that induces the secondary earners to leave the labor force. (See Liebman, 1998, for a discussion.)

22 See Liebman (1998).

23 See Alm, Dickert-Colin, and Whittington (1999) for an excellent review. 
dren and that their effects can dwarf the traditional tax-bracket aspects. ${ }^{24}$ There is no one right way to calculate marriage penalties, because one cannot infer whether earnings would change if the couple were married versus unmarried or who would get custody of the children. ${ }^{25}$ But if one assumes that all of the children would live with one of the parents in the event that the couple were not married and that earnings of each parent would remain unchanged, the effects of the child tax credits on marriage are easy to illustrate.

Married couples will generally have more combined income than the custodial parent would alone, simply because another potential earner has been added to the household. If so, a married couple will be further along the income spectrum than a single parent would be. Comparing the child benefits at the income of the single parent alone with those available at the combined income of the couple shows the effect of child benefits on marriage incentives.

If a custodial parent of two children with zero earnings (relying on welfare) marries a single man with $\$ 12,000$ in earnings, the couple will gain nearly $\$ 4,000$ in child tax benefits, all from the EITC. At her previous zero earnings, there are no child tax benefits. At $\$ 12,000$, the family gets the full EITC. In effect, her children and his earnings allow them to qualify for the EITC. Indeed, for mothers with no earnings, there always will be sizable marriage rewards created by the tax benefits for children, because at all income levels above zero, child tax benefits are sizable.

But if the mother were already earning $\$ 12,000$ and she married the same man earning $\$ 12,000$, child benefits would fall by roughly $\$ 1,200$ and serve as a marriage penalty. At $\$ 24,000$ the child benefits are smaller than at $\$ 12,000$. In this case, his earnings reduce "her" EITC. In any region where, by marrying, the mother moves up the child-benefit scale, child benefits will be rewarding marriage. But when the combined income from marriage pushes her down the benefit schedule, it will penalize matrimony. Given the large valley in child tax benefits, and the low incomes of many working women, it is quite common for child tax benefits to lead to sizable marriage penalties in situations where the mother is working.

Table 4, which is modeled after a table by Wheaton (1998), illustrates the tax-based marriage penalties and rewards for couples in different

24 Feenberg and Rosen (1995) describe how EITC expansions have increased marriage penalties.

25 For a valuable discussion of alternative ways of calculating marriage penalties, see Bull, Holtzblatt, Nunns, and Rebelein (1999). 


\section{TABLE 4}

1999 Total Marriage Rewards and Penalties and Marriage Rewards and Penalties from Child Tax Benefits (in Parentheses)

\begin{tabular}{lccccr} 
& \multicolumn{5}{c}{ Marriage reward (\$) at percentage of income } \\
$\begin{array}{l}\text { Couple's total } \\
\text { income (\$) }\end{array}$ & $0 \%$ & $25 \%$ & $50 \%$ & $75 \%$ & $100 \%$ \\
\cline { 2 - 6 } 12,000 & 4,559 & 2,814 & 1,092 & -14 & 0 \\
& $(3,816)$ & $(2,521)$ & $(1,092)$ & $(-14)$ & $(-435)$ \\
20,000 & 4,171 & 1,421 & $-1,163$ & $-1,400$ & 0 \\
& $(3,323)$ & $(1,323)$ & $(-646)$ & $(-1,190)$ & $(-540)$ \\
35,000 & 2,959 & $-2,140$ & $-2,707$ & $-1,543$ & 540 \\
& $(1,825)$ & $(-1,675)$ & $(-2,190)$ & $(-1,026)$ & $(0)$ \\
50,000 & 4,909 & $-2,399$ & $-1,693$ & -518 & 651 \\
& $(1,825)$ & $(-2,493)$ & $(-1,175)$ & $(0)$ & $(-715)$ \\
75,000 & 6,536 & $-1,370$ & $-1,694$ & $-1,382$ & 2,113 \\
& $(2,540)$ & $(-1,399)$ & $(715)$ & $(0)$ & $(0)$ \\
\hline
\end{tabular}

Notes: Positive numbers indicate marriage rewards; negative numbers, marriage penalties. Total tax rewards or penalties equal change in total tax liabilities. Child-benefit rewards or penalties are the change in the combined value of EITC, dependent exemption, and child tax credit. No dependentcare benefits are included. It is assumed that each person's income will remain unchanged if couple is unmarried, that children will go with wife, and that all persons use standard deduction.

situations. The couples' combined total income is shown on the left side of the table, and the share of that income earned by the woman is shown across the top. In constructing this table, we assumed that all income is earned income, that both the man's and the woman's earnings would remain unchanged if they were living separately, that the woman would retain custody of the children, and that she would file as a head of household and the man as a single taxpayer. We have ignored any child-care expenses that might lead to dependent-care credits. These are strong assumptions, but they help to illustrate the underlying tax structures.

The table shows the total marriage rewards or penalties, and then in parentheses it shows the marriage reward or penalty associated with changing child benefits alone. As one would expect, in couples where all the income is earned by the man, there are large marriage rewards. For a man earning $\$ 20,000$ and an unemployed woman with two children (so the woman is earning 0 percent of their combined income), the tax system provides a $\$ 4,171$ reward to marriage-effectively raising their income by more than 25 percent. Yet, surprisingly, if the situation were 
reversed and an unemployed man were to marry a mother with two children who is earning $\$ 20,000$ (so the woman is earning 100 percent of the income), there are no marriage rewards at all. This result is entirely due to the treatment of children in the tax system. A single individual earning $\$ 20,000$ would owe almost $\$ 2,000$ in taxes. But if he were to marry an unemployed mother of two, he would move to the joint tax schedule and qualify for additional child tax benefits. When the situation is reversed, the woman would already be getting the tax benefits of children.

By contrast, in cases where the incomes of the parties are more equal, there are often large tax penalties. For a couple with $\$ 35,000$ of income earned in equal portions, the marriage tax is over $\$ 2,700$. And interestingly, most of that is caused by the change in child tax benefits-not the variation in brackets between singles and couples. Indeed, it is striking that for couples earning $\$ 50,000$ or less, where both partners have earnings, a very large share of the marriage penalty or reward is the result of the effect on child tax credits, not the more traditional features of the tax code. Even in couples earning $\$ 75,000$, when the wife is earning a quarter of the total, the child tax penalty is sizable.

Just as in the case of marginal tax rates, for lower-income couples, one cannot think about the total rewards or penalties to marriage independently of the transfer system. Unemployed single mothers can usually collected TANF, at least for a period, and will lose considerable benefits if they marry. The loss of these transfer and welfare benefits almost always adds additional marriage penalties. Thus, when the tax code has marriage rewards, it helps offset penalties in the transfer system. When taxes create penalties, they exacerbate marriage disincentives. For working couples with income around $\$ 25,000$ the combined marriage penalty from the various sources can reach 20 percent of disposable income.

Unlike the case for labor-supply incentives, there is thus far little evidence that these changing tax incentives have altered marriage behavior in a sizable way. Ellwood (2000) found only limited and ambiguous evidence of any marriage increases in the group for whom marriage penalties were reduced, or decreases in marriage among those for whom marriage incentives turned more negative. Dickert-Conlin and Houser (1999) find little impact of the EITC changes on female headship. And Eissa and Hoynes (1999b) find that reductions in marriage penalties have modest effects on marriages among low-income women.

Given that child tax benefits create large marriage rewards in some cases, and smaller, but still sizable, marriage penalties in others, their overall behavioral effect is uncertain. Nonetheless, policymakers may be 
troubled by the marriage penalties both on the basis of fairness and because of the potential for behavioral effects in the long run. Especially at a time when lawmakers are considering relieving marriage tax penalties in other parts of the tax code, those created by the middle-class parent penalty seem particularly important.

\section{OPTIONS FOR REFORM}

There are several possible ways to remove some or all of the high marginal tax rates and marriage penalties for middle-income families created by child benefits. One could cut benefits for low-income families. This would have the effect of lowering the income of relatively poor families with children and reducing the incentives for parents to leave welfare for work. Since the EITC and other worker supports seem to have had a strong positive effect on work by low-wage single parents and have helped to reduce welfare caseloads, such a policy option seems unlikely to be adopted. Indeed, most recent developments in social policy are moving in the opposite direction and providing greater support to working parents who are poor or near-poor.

The alternative is to fill in all or part of the middle-class valley in childlinked tax benefits so that middle-class families get the same benefits as the rich and poor. There is an obvious argument of fairness for such a plan, as well as potentially positive effects on work and marriage incentives. On the other hand, such plans will inevitably involve additional expenditures. At a time when tax cuts are being widely discussed by both parties, however, providing more equal tax benefits for middleclass families might be considered.

We examine five options for reducing the middle-class parent penalty by providing greater support to middle-income families. All of these are designed to penalize virtually no taxpayer while equalizing child tax benefits across income groups (and in some cases raising benefits for some low-income families)

\subsection{Option 1: A \$1,270-per-Child Partially Refundable Tax Credit for Working Families}

Replace the existing child tax credit and the dependent exemption with a $\$ 1,270-$ per-child partially refundable tax credit (where the refundability is integrated into the phaseout of the existing EITC). The credit of $\$ 1,270$ is chosen because it represents the value of the existing non-refundable credit and dependent-child exemption for families in the 28-percent tax bracket (the highest bracket for married couples where the full child tax 


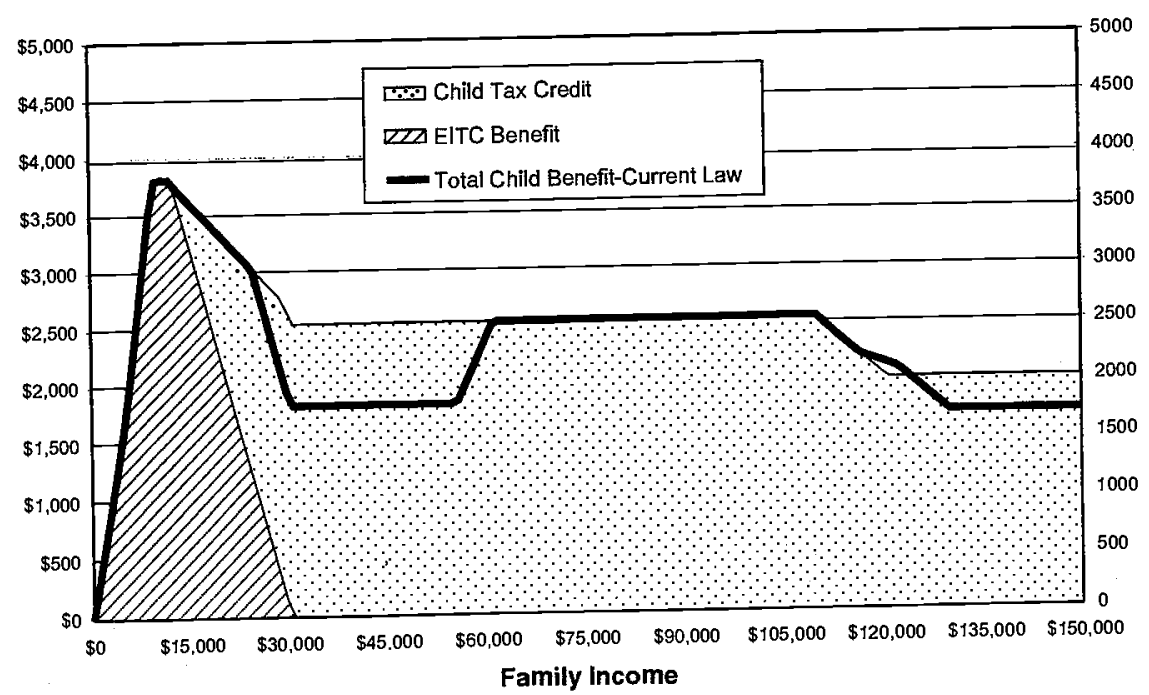

FIGURE 10. 1999 Tax Benefits Associated with Having Two

Children-Married Couples under Option 1 and Current Law $(\$ 1,270$ Partially Refundable Child Tax Credit)

credit is available). Families with incomes below the EITC phasedown point $(\$ 12,500)$ would simply get their EITC. The credit above that level would be refundable, but the maximum refund would be the EITC or the child tax credit, whichever is more. ${ }^{26}$ This would preserve the positive work incentive of the EITC while reducing the marginal tax rates and marriage penalties for middle-income families. The new child tax credit would be phased down to $\$ 1,000$ for families with incomes over $\$ 110,000$ $(\$ 75,000$ for single household heads) to maintain the current pattern of child tax benefits phasing down for high-income taxpayers while still ensuring that higher-income taxpayers would be no worse off than under current law.

The effect of this provision on child tax benefits for a married couple with two children is illustrated on Figure 10. It essentially is a proposal to fill in the valley in child benefits between $\$ 30,000$ and $\$ 60,000$. Figure 11 compares the marginal tax rates faced by married couples with two children at different incomes under this proposal with those under current law, showing that in the EITC phaseout region marginal tax rates would fall below 30 percent.

${ }^{26}$ Any remaining credit could be used to offset taxes, but not to increase the refundable portion of the credit. 


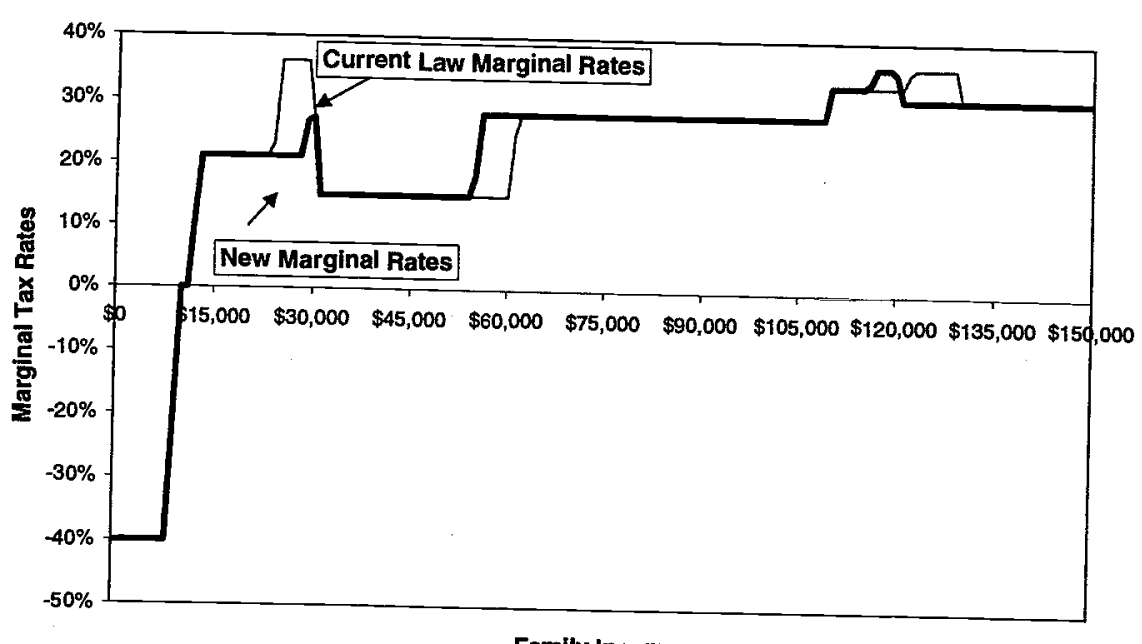

Family Income

FIGURE 11. Marginal Tax Rate for Married Couple with Two Children under Option 1 and Current Law (\$1,270 Partially Refundable Child Tax Credit)

\subsection{Option 2: Raise the Existing Child Tax Credit to $\$ 1,000$ Per Child}

President George W. Bush and others have proposed raising the child tax credit to $\$ 1,000 .{ }^{27}$ This plan is illustrated in Figure 12. By itself, such an increase in the child credit would raise the aid that most middle- and upper-income families receive. It would also reduce the number of taxpayers facing high marginal tax rates (Figure 13) and reduce marriage penalties, because many taxpayers who currently face both the EITC phaseout and the 15-percent federal income tax rate would have their pre-EITC tax liability reduced to zero. But families with two children and incomes below $\$ 33,000$ could not take full advantage of the benefit, because the credit would remain non-refundable; and a sizable middle-class parent penalty would remain.

\subsection{Option 3: A \$1,770-per-Child Partially Refundable Tax Credit for Working Families}

This plan would be something of a combination of the first two plans. It would, in effect, fill in the remaining valley left from the $\$ 1,000$ tax credit

${ }^{27}$ President Bush has also suggested phasing it out at much higher incomes and has proposed other tax changes not related to children, which we do not simulate here. 


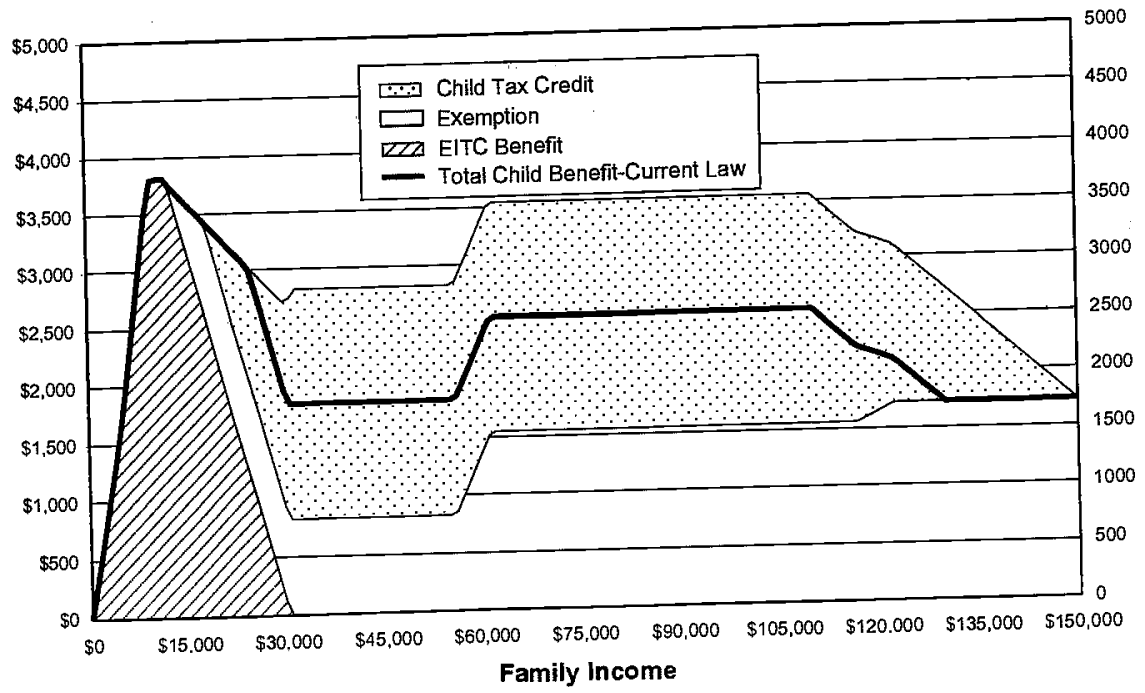

FIGURE 12. 1999 Tax Benefits Associated with Having Two Children-Married Couples under Option 2 and Current Law (\$1,000 Non-refundable Child Tax Credit)

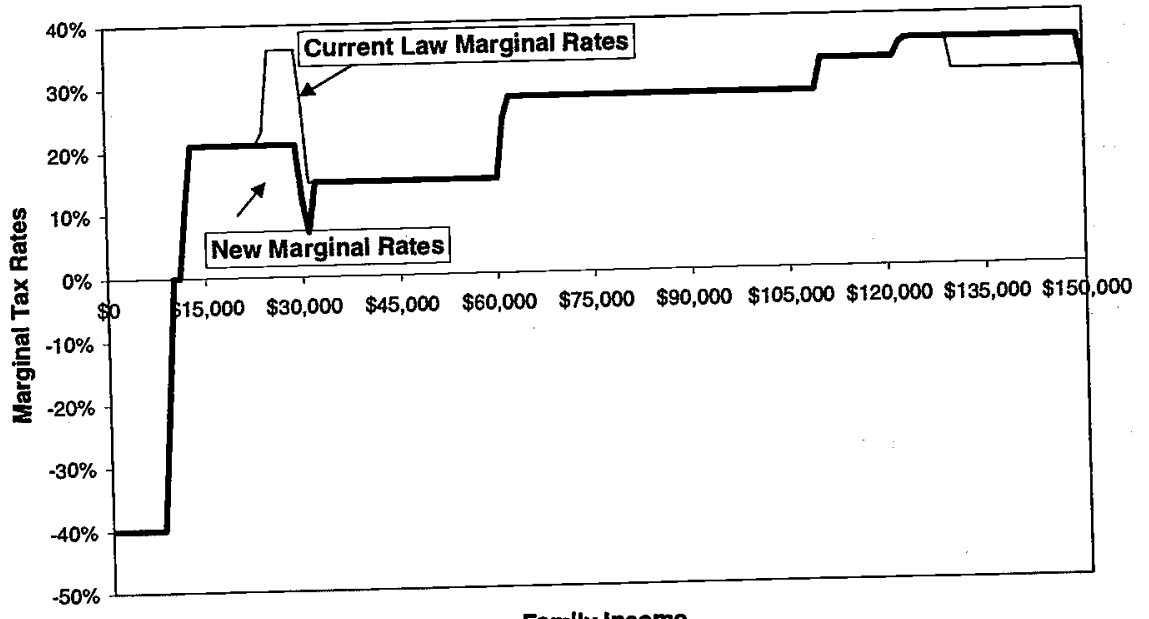

FIGURE 13. Marginal Tax Rate for Married Couple with Two Children under Option 2 and Current Law (\$1,000 Non-refundable Child Tax Credit) 


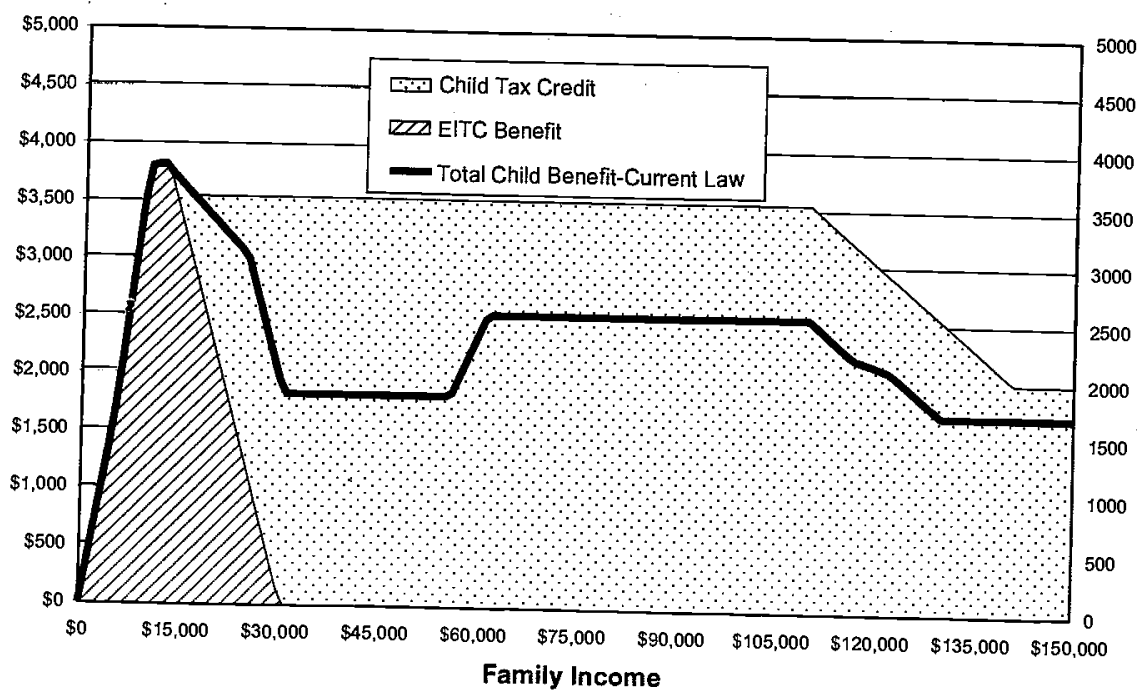

FIGURE 14. 1999 Tax Benefits Associated with Having Two Children-Married Couples under Option 3 and Current Law $(\$ 1,770$ Partially Refundable Child Tax Credit)

of option 2 so that families with incomes between $\$ 20,000$ and $\$ 60,000$ would get nearly the same tax benefits as those at incomes of $\$ 10,000$ or $\$ 70,000$. It would operate identically to option 1 with a higher benefit level-the new credit would replace the child exemption and child credit. Persons below $\$ 10,000$ would qualify only for the EITC. The maximum refund would be the EITC or the child credit, whichever is more. This plan is illustrated in Figure 14, and its impact on marginal tax rates in Figure 15.

\subsection{Option 4: No EITC Phaseout until Higher Incomes}

The simplest and most complete way to end the middle-class parent penalty would be to eliminate the exemption and child tax credit, and simply not allow the EITC to phase out at all until family income reaches $\$ 110,000$ and then phase it down to $\$ 1,000$ per child. Thus any families with earnings above the EITC maximum would receive the full benefit. This plan is illustrated in Figures 16 and 17.

\subsection{Option 5: A Three-Step Refundable Working-Family Tax Credit Integrated into the Tax Code}

This option was created in an attempt to get many of the benefits of the previous two options in reduced tax rates and marriage penalties at a 


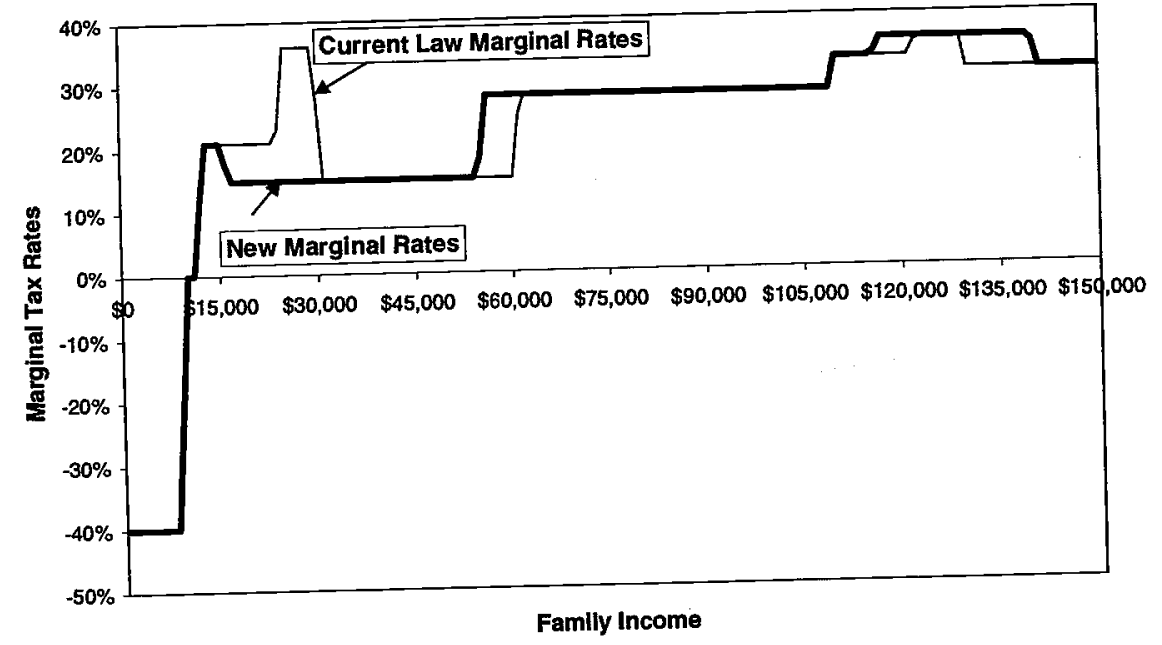

FIGURE 15. Marginal Tax Rate for Married Couple with Two Children under Option 3 and Current Law (\$1,770 Partially Refundable Child Tax Credit)

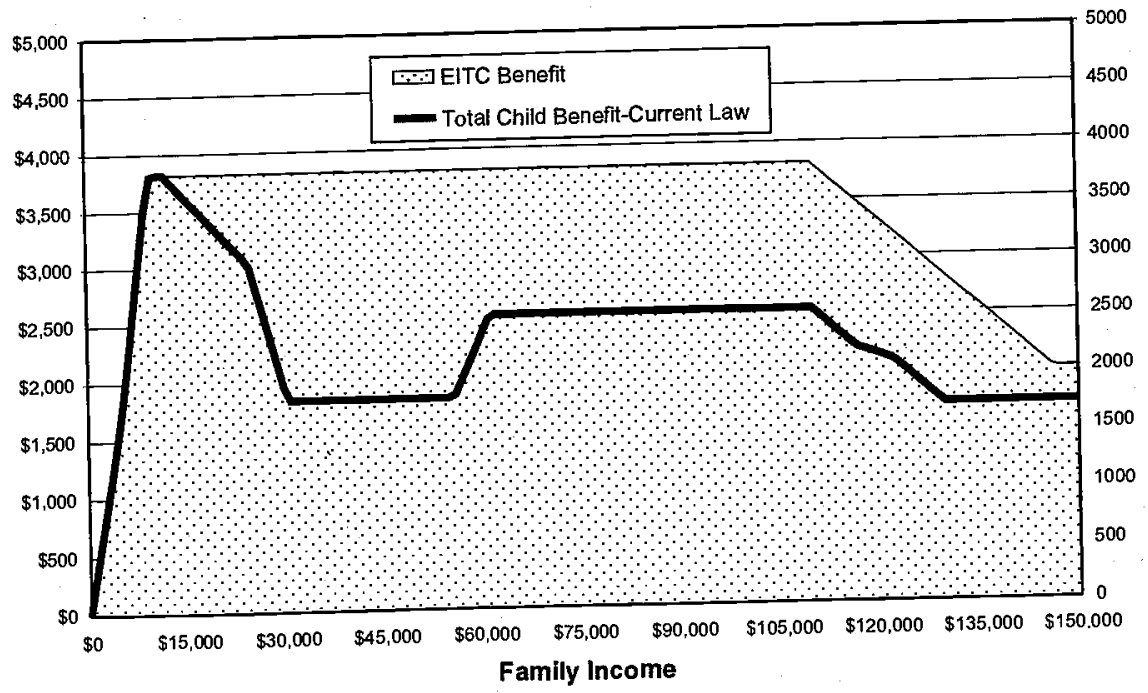

FIGURE 16. 1999 Tax Benefits Associated with Having Two Children-Married Couples under Option 4 and Current Law (Extend EITC) 


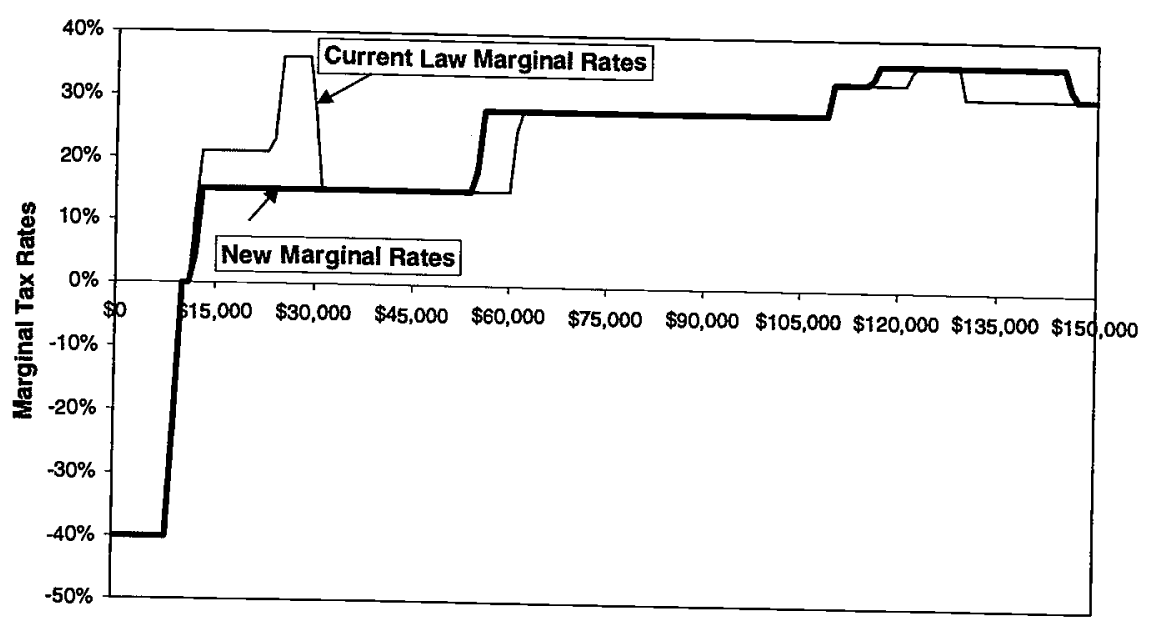

Family Income

FIGURE 17. Marginal Tax Rate for Married Couple with Two Children under Option 4 and Current Law (Extend EITC)

lower cost. This option would replace the child credit, dependent exemption, and EITC with a working-family tax credit that phases in like the EITC and then has three steps as illustrated in Figure 18. The first step would be for low-income working families, with benefits phasing in in the same way as the current EITC, and would reach the same maximums for families with one or two children $(\$ 2,312$ for one child, $\$ 3,816$ for two children). For low-income families with more than two children, a third tier would be added to the old EITC with a phase-in rate of 46 percent and a maximum benefit of $\$ 4,300$. Once a family's income reaches this first plateau, benefits would remain constant until the family's income reached $\$ 18,000$, when they would decline at a 10 -percent phasedown rate to a level of $\$ 1,500$ per child for the first two children, and $\$ 1,270$ for each additional child. Then, when income reached $\$ 110,000$, the benefit would phase down at a 5-percent rate to the third tier of $\$ 1,000$ per child. Under this plan the three key child benefits would be integrated into a relatively simple three-step benefit structure with benefits for every taxpayer that are as high as or higher than benefits under current law. The resulting marginal tax rates are shown in Figure 19.

\subsection{Evaluation of the Options}

Table 5 provides a summary of the cost and other impacts of the five reform options. Current-law child benefits (from dependent exemp- 


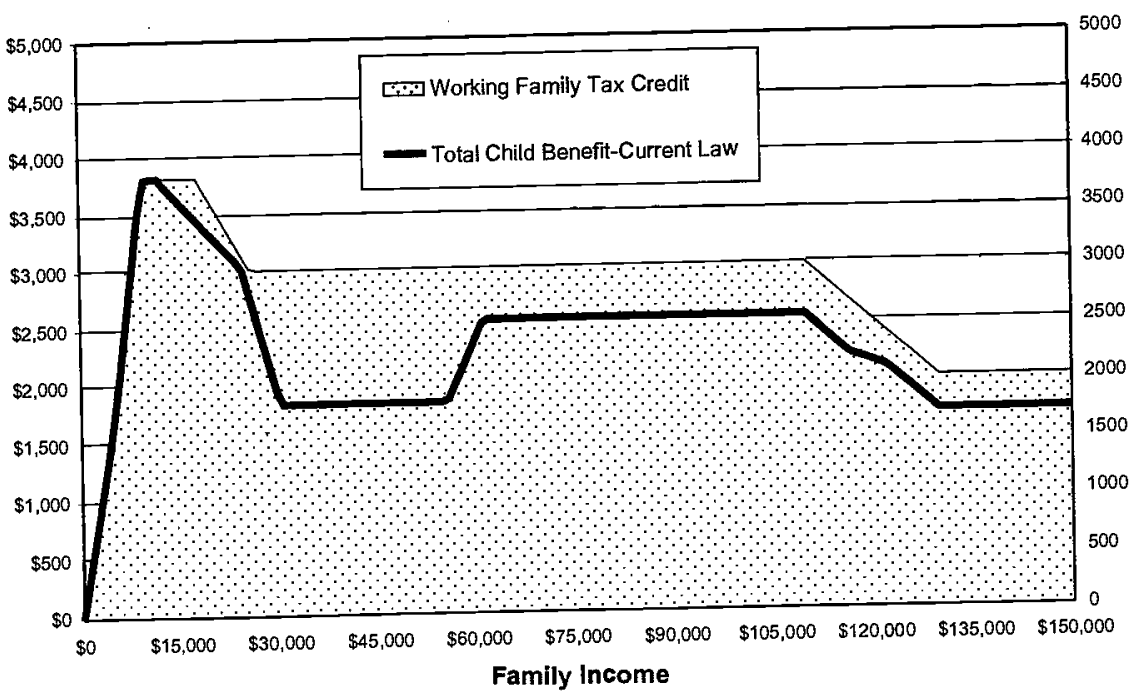

FIGURE 18. 1999 Tax Benefits Associated with Having Two

Children-Married Couples under Option 5 and Current Law (ThreeStep Working-Family Tax Credit)

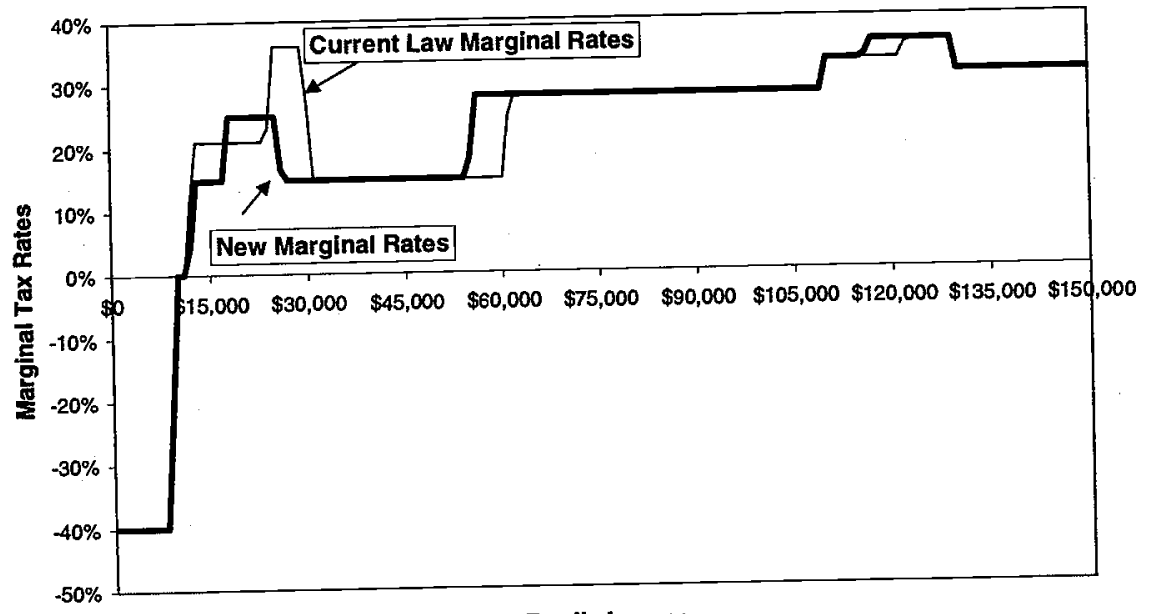

Family Income

FIGURE 19. Marginal Tax Rate for Married Couple with Two Children under Option 5 and Current Law (Three-Step Working-Family Tax Credit) 


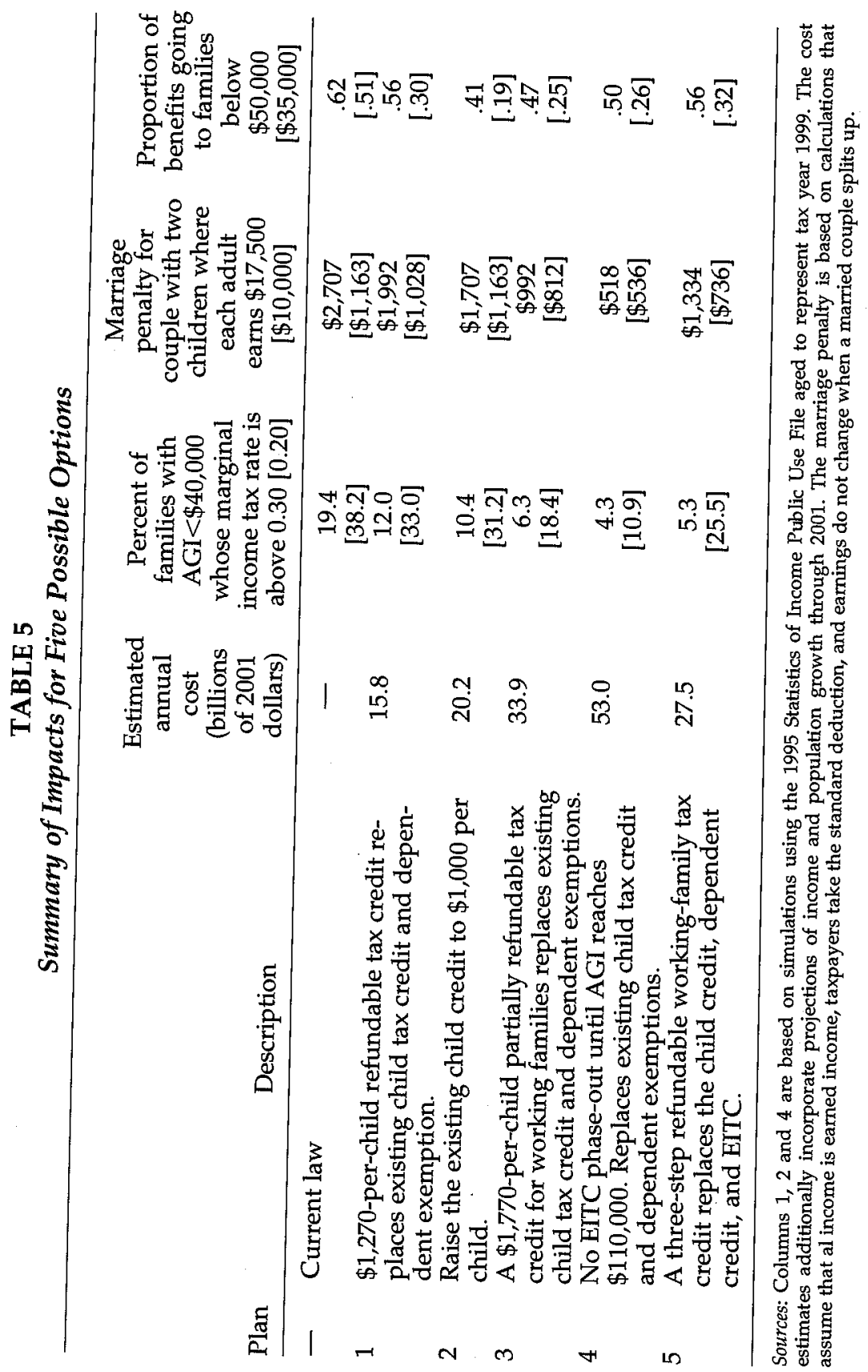


tions, the EITC, and the child credit) total $\$ 85$ billion. The first columns of numbers in Table 5 provides a summary of the additional costs associated with each plan for FY 2001. All significantly increase the total cost of child benefits. Not surprisingly, option 3 (a \$1,770 partially refundable credit) and option 4 (extending the EITC) are the most expensive, because their benefits are the most expansive. In contrast, option 1 (a $\$ 1,270$-per-child partially refundable credit) costs only $\$ 15.8$ billion per year; option 2 (raising the child credit to $\$ 1,000$ per child) costs $\$ 20$ billion per year, and option 5 (the three-step refundable working-family tax credit) costs $\$ 27.5$ billion per year.

The next column of Table 5 summarizes the impact of the plans on the marginal tax rates of low- and middle-income taxpayers with children. Under current law, 19.4 percent of families with children and AGI below $\$ 40,000$ face marginal federal personal income tax rates of 30 percent or more, and 38.2 percent face rates of 20 percent or more. The first reform, replacing the child credit and dependent exemption with a \$1,270-perchild partially refundable tax credit, reduces this share with marginal tax rates above 30 percent by nearly 40 percent, to 12 percent. Expanding the existing child credit from $\$ 500$ to $\$ 1,000$ per child under option 2 reduces the fraction of these taxpayers with marginal tax rates above 30 percent even further, to 10.4 percent.

The three plans presented in the last three rows accomplish even more. The \$1,770-child-credit option reduces the share of these taxpayers facing very high marginal tax rates to 6 percent, a reduction of two-thirds compared to current law. Eliminating the EITC phase-out reduces the share to 4 percent. Note that these last two options greatly reduce the fraction of taxpayers with marginal tax rates between 20 and 30 percent as well. In the no-EITC-phaseout option, 89 percent of taxpayers with children and incomes below $\$ 40,000$ have marginal tax rates below 20 percent, compared with only 62 percent under current law. The last option, the three-step refundable credit, is as successful at reducing the share of taxpayers with marginal tax rates above 30 percent as the two previous options, even though it costs only $\$ 28$ billion. However, it does less to reduce the share of taxpayers with marginal tax rates between 20 and 30 percent than the more expensive options do.

The next column of Table 5 summarizes each option's impact on marriage penalties. We focus on marriage penalties for families in the $\$ 20,000-\$ 35,000$ range where the woman earns 50 percent of the household income, because this is where the plans have their most significant differences. Further details of the impact on marriage penalties for other types of families are available in Table 6. Under current law, a married couple with two children in which each spouse earns $\$ 17,500$ faces a 
TABLE 6

1999 Total Marriage Rewards and Penalties under Alternative Options

\begin{tabular}{|c|c|c|c|c|c|c|}
\hline \multirow{2}{*}{$\begin{array}{l}\text { Couple's } \\
\text { total } \\
\text { income }\end{array}$} & \multirow[b]{2}{*}{ Option } & \multicolumn{5}{|c|}{$\begin{array}{c}\text { Marriage reward at percentage of income } \\
\text { earned by woman }\end{array}$} \\
\hline & & $0 \%$ & $25 \%$ & $50 \%$ & $75 \%$ & $100 \%$ \\
\hline$\$ 12,000$ & $\begin{array}{l}\text { Current law } \\
\text { 1: } \$ 1,270 \text { flat credit } \\
\text { 2: } \$ 1,000 \text { existing child } \\
\text { credit }\end{array}$ & $\begin{array}{l}4,559 \\
4,559 \\
4,559\end{array}$ & $\begin{array}{l}2,814 \\
2,814 \\
2,814\end{array}$ & $\begin{array}{l}1,092 \\
1,092 \\
1,092\end{array}$ & $\begin{array}{l}-14 \\
-14 \\
-14\end{array}$ & $\begin{array}{l}0 \\
0 \\
0\end{array}$ \\
\hline & $\begin{array}{l}\text { 3: } \$ 1,770 \text { flat credit } \\
\text { 4: Extend EITC } \\
\text { 5: Three-step tax credit }\end{array}$ & $\begin{array}{l}4,559 \\
4,559 \\
4,559\end{array}$ & $\begin{array}{l}2,814 \\
2,814 \\
2,814\end{array}$ & $\begin{array}{l}1,092 \\
1,092 \\
1,092\end{array}$ & $\begin{array}{l}-14 \\
-14 \\
-14\end{array}$ & $\begin{array}{l}435 \\
435 \\
435\end{array}$ \\
\hline$\$ 20,000$ & $\begin{array}{l}\text { Current law } \\
1: \$ 1,270 \text { flat credit } \\
\text { 2: } \$ 1,000 \text { existing child } \\
\text { credit }\end{array}$ & $\begin{array}{l}4,171 \\
4,171 \\
4,171\end{array}$ & $\begin{array}{l}1,421 \\
1,421 \\
1,421\end{array}$ & $\begin{array}{l}-1,163 \\
-1,028 \\
-1,163\end{array}$ & $\begin{array}{l}-1,400 \\
-1,400 \\
-1,400\end{array}$ & $\begin{array}{l}0 \\
0 \\
0\end{array}$ \\
\hline & $\begin{array}{l}\text { 3: } \$ 1,770 \text { flat credit } \\
\text { 4: Extend EITC } \\
\text { 5: Three-step tax credit }\end{array}$ & $\begin{array}{l}4,388 \\
4,664 \\
4,464\end{array}$ & $\begin{array}{l}1,638 \\
1,914 \\
1,714\end{array}$ & $\begin{array}{l}-812 \\
-536 \\
-736\end{array}$ & $\begin{array}{r}-1,183 \\
-557 \\
-757\end{array}$ & $\begin{array}{l}217 \\
540 \\
540\end{array}$ \\
\hline$\$ 35,000$ & $\begin{array}{l}\text { Current law } \\
\text { 1: } \$ 1,270 \text { flat credit } \\
\text { 2: } \$ 1,000 \text { existing child } \\
\text { credit }\end{array}$ & $\begin{array}{l}2,959 \\
3,674 \\
3,959\end{array}$ & $\begin{array}{l}-2,140 \\
-1,425 \\
-1,140\end{array}$ & $\begin{array}{l}-2,707 \\
-1,992 \\
-1,707\end{array}$ & $\begin{array}{l}-1,543 \\
-1,543 \\
-1,291\end{array}$ & $\begin{array}{l}540 \\
540 \\
540\end{array}$ \\
\hline & $\begin{array}{l}\text { 3: } \$ 1,770 \text { flat credit } \\
\text { 4: Extend EITC } \\
\text { 5: Three-step tax credit }\end{array}$ & $\begin{array}{l}4,674 \\
4,950 \\
4,134\end{array}$ & $\begin{array}{l}-425 \\
-149 \\
-965\end{array}$ & $\begin{array}{r}-992 \\
-518 \\
-1,334\end{array}$ & $\begin{array}{l}-631 \\
-631 \\
-631\end{array}$ & $\begin{array}{l}540 \\
540 \\
540\end{array}$ \\
\hline 550,000 & $\begin{array}{l}\text { Current law } \\
\text { 1: } \$ 1,270 \text { flat credit } \\
2: \$ 1,000 \text { existing child } \\
\text { credit }\end{array}$ & $\begin{array}{l}4,909 \\
5,624 \\
5,909\end{array}$ & $\begin{array}{l}-2,399 \\
-1,684 \\
-1,399\end{array}$ & $\begin{array}{l}-1,693 \\
-1,538 \\
-1,253\end{array}$ & $\begin{array}{l}-518 \\
-518 \\
-518\end{array}$ & $\begin{array}{r}651 \\
1,366 \\
651\end{array}$ \\
\hline & $\begin{array}{l}\text { 3: } \$ 1,770 \text { flat credit } \\
\text { 4: Extend EITC } \\
\text { 5: Three-step tax credit }\end{array}$ & $\begin{array}{l}6,624 \\
6,900 \\
6,084\end{array}$ & $\begin{array}{r}-684 \\
94 \\
-723\end{array}$ & $\begin{array}{l}-538 \\
-518 \\
-634\end{array}$ & $\begin{array}{l}-518 \\
-518 \\
-518\end{array}$ & $\begin{array}{l}1,366 \\
1,366 \\
1,366\end{array}$ \\
\hline 75,000 & $\begin{array}{l}\text { Current law } \\
\text { 1: } \$ 1,270 \text { flat credit } \\
\text { 2: } \$ 1,000 \text { existing child } \\
\text { credit }\end{array}$ & $\begin{array}{l}6,536 \\
6,536 \\
7,536\end{array}$ & $\begin{array}{r}-1,370 \\
-1,370 \\
-370\end{array}$ & $\begin{array}{l}-1,694 \\
-2,409 \\
-1,694\end{array}$ & $\begin{array}{l}-1,382 \\
-1,382 \\
-1,382\end{array}$ & $\begin{array}{l}2,113 \\
2,113 \\
2,113\end{array}$ \\
\hline & $\begin{array}{l}\text { 3: } \$ 1,770 \text { flat credit } \\
\text { 4: Extend EITC } \\
\text { 5: Three-step tax credit }\end{array}$ & $\begin{array}{l}7,536 \\
7,812 \\
6,996\end{array}$ & $\begin{array}{r}-370 \\
29 \\
-713\end{array}$ & $\begin{array}{l}-2,409 \\
-2,409 \\
-2,409\end{array}$ & $\begin{array}{l}-1,382 \\
-1,382 \\
-1,382\end{array}$ & $\begin{array}{l}2,113 \\
2,113 \\
2,113\end{array}$ \\
\hline
\end{tabular}

Notes: See Table 4. 
marriage penalty of $\$ 2,707$. Options 1 and 2 reduce this by about onethird, to $\$ 1,992$ and $\$ 1,707$ respectively. Options 3 and 4 go much further, reducing marriage penalties to $\$ 992$ and $\$ 518$. Given the pattern of benefits, this should come as no surprise. The less the difference between the maximum value of the EITC and the value of child benefits for moderate-income families, the smaller the marriage penalty, and these two options show little or no fall in benefits as one moves from low to moderate incomes. Finally, option 5 (the three-step working-family tax credit) performs reasonably well here. While it does not reduce marriage penalties as much as the most expensive options, it reduces them far more dramatically than the $\$ 1,270$ flat credit or the expansion of the child credit to $\$ 1,000 . .^{28}$

Figure 20 shows the distribution of dollars spent under these options by AGI. In most of the plans, the bulk of the dollars go to taxpayers with incomes between $\$ 15,000$ and $\$ 75,000$. The main exception is option 2 (raising the child credit to $\$ 1,000$ ) and to a lesser extent the closely related option 3 , which transfer substantial fractions of their dollars to taxpayers with incomes above $\$ 75,000$. The distributional impacts of these plans is summarized in the last column of Table 5, which shows the proportion of benefits going to families with AGI below $\$ 50,000$ and the proportion going to families with AGI below $\$ 35,000$. Under current law, 62 percent of child tax benefits go to families with incomes below $\$ 50,000$, while 51 percent go to families below $\$ 35,000$. Option 1 (the $\$ 1,270$-per-child refundable credit) and option 5 (the three-step credit) provide almost as high a share of their benefits to families with incomes below $\$ 50,000$ as under current law (though much smaller shares to taxpayers under $\$ 35,000)$. In contrast, option 2 (raise the child credit to $\$ 1,000$ ) provides only 41 percent of its benefits to families with incomes below $\$ 50,000$ and only 19 percent to families with incomes below $\$ 35,000$. Options 3 and 4 are somewhere in the middle, providing more dollars to low- and middle-income families than option 2, but less than options 1 and 5 .

One obvious result here is that the greater the benefits given to moderate-income parents, the better these plans perform in reducing tax rates and marriage penalties. The extreme plan, simply extending the EITC all the way to $\$ 110,000$ in AGI, virtually eliminates the adverse incentives. But of course, the plans that accomplish the most are also the most expensive.

28 Note that in the more detailed Table 6 there are a few circumstances where marriage penalties rise slightly for some higher-income couples. For them the rising child benefits associated with higher incomes served as a modest marriage reward that these plans tend to reduce. 


\section{Options 1, 2, and 3}

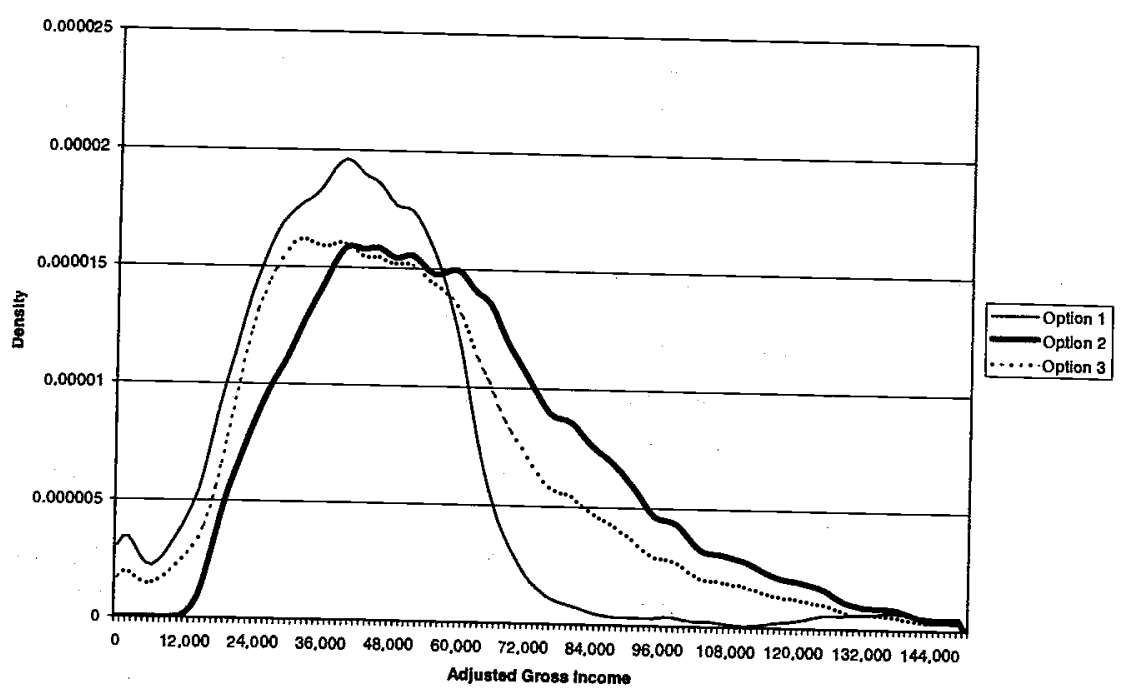

Options 2, 4, and 5

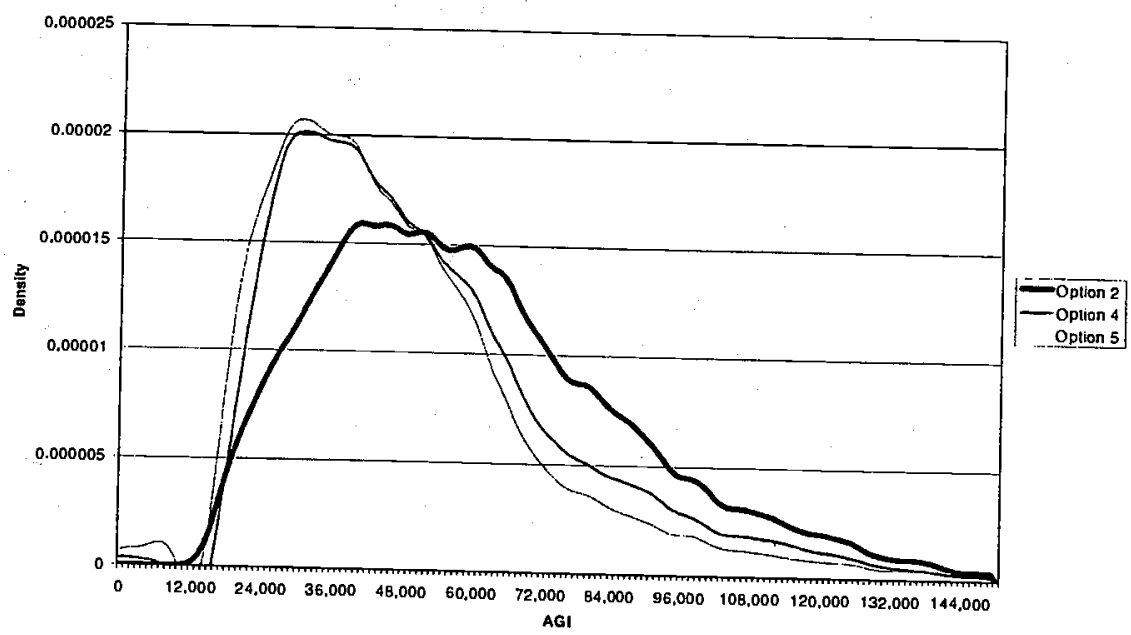
FIGURE 20. Distribution of Dollars Spent under Each Reform Option
by AGI 


\section{CONCLUSION}

The combination of child tax benefits creates a U-shaped benefit pattern by income. The $U$ shape arises largely from the introduction of new supports for low-income working families in recent years that are credited with significantly increasing the work of low-income workers. But they also create a middle-class parent penalty that creates high marginal tax rates and sizable marriage penalties for some families.

The obvious way to reduce the parent penalty is to increase the tax benefits associated with children for middle-income families. This approach leads to significant benefits in incentives and equity, but since this is the densest part of the income distribution, such plans are expensive.

If the nation considers an expansion of the child tax credit to $\$ 1,000$, as has been suggested by some in Congress and by George W. Bush, then making it partially refundable by converting it to a flat $\$ 1,770$ credit and eliminating the child exemptions will target more of the benefits on middle-income taxpayers and more significantly reduce high marginal tax rates and marriage penalties for low-to moderate-income families. Other, less costly options, including the replacement of the current set of childrelated benefits with a three-step working-family tax credit, would significantly reduce marginal tax rates and marriage penalties at a lower cost.

Inevitably, deciding on the priority we should assign to reducing the middle-class parent penalty will depend on perceptions of fairness, political priorities, and estimated impacts on incentives. At the current time the adverse tax rates and marriage penalties have not been shown to create major distortions in behavior in work or marriage in these income ranges. In contrast, the positive work incentives created by the EITC seem clearly to have increased work by low-income workers, especially single parents. Some may conclude that alleviating the middle-class parent penalty is not worth the cost. If large tax cuts are seriously considered, however, the options discussed in this paper not only would be targeted on middle-class families, but also would significantly reduce adverse incentives while maintaining the positive work incentives for low-income workers.

\section{REFERENCES}

Alm, James, Stacy Dickert-Conlin, and Leslie A. Whittington (1999). "Policy Watch: The Marriage Penalty." Journal of Economic Perspectives 13 (no. 3, Summer):193-204.

Blank, Rebecca, David Card, and Philip Robbins (2000). "Financial Incentives for Increasing Work and Income among Low-Income Families." In Finding Jobs: 
Work and Welfare Reform, Rebecca Blank and David Card (eds.). New York: Russell Sage.

Bull, Nicholas, Janet Holtzblatt, James R. Nunns, and Robert Rebelein (April 1999). "Defining and Measuring Marriage Penalties and Bonuses," U.S. Department of the Treasury, Office of Tax Analysis, OTA Paper 82.

Cameron, Stephen V., and James J. Heckman (1999). "The Dynamics of Educational Attainment for Blacks, Hispanics, and Whites." NBER Working Paper
no. 7249 .

Cherry, Robert (1998). "Universalizing the EITC: A Progressive Pro-family Agenda." Brooklyn, NY: Brooklyn College.

, and Max B. Sawicky (2000). "Giving Tax Credit Where Credit Is Due. A 'Universal Unified Child Credit' That Expands the EITC and Cuts Taxes for Working Families." Briefing Papers. Washington, DC: Economic Policy Institute.

Committee on Ways and Means (1998). 1998 Green Book. Background Material and Data on Programs under the Jurisdiction of the Committee on Ways and Means. Washington, DC: U.S. Government Printing Office.

Dickert-Conlin, Stacy, and Scott Houser (1999). "EITC, AFDC and The Female Headship Decision." Mimeo. Syracuse University.

Dynarski, Susan (June 2000). Hope for Whom? Financial Aid for the Middle Class and Its Impact on College Attendance," NBER Working Paper No. 7756.

Eissa, Nada, and Hilary Hoynes (1999a). "The Earned Income Tax Credit and the Labor Supply of Married Couples." Mimeo. University of California at Berkeley.

-, and - (1999b). "Good News for Low-Income Families? Tax-Transfer Schemes and Marriage." Mimeo. University of California, Berkeley.

-, and Jeffrey B. Liebman (1996). "Labor Supply Response to the Earned Income Tax Credit." Quarterly Journal of Economics 112(no. 2, May):605-637.

Ellwood, David T. (1996). "Welfare Reform As I Knew It." The American Prospect 26 (May-June).

(2000). "The Impact of the Earned Income Tax Credit and Social Policy Reforms On Work, Marriage, and Living Arrangements." National Tax Journal Special Issue on the Earned Income Tax Credit, Volume L111, No. 4, Part 2 December. Family Thomas J. Kane (2000). "Who Is Getting A College Education: Family Background and the Growing Gaps in Enrollment," in Securing the Future, edited by Sheldon Danziger and Jane Waldfogel. New York: Russell Sage.

Feenberg, Daniel R., and Harvey S. Rosen (1995). "Recent Developments in the Marriage Tax." National Tax Journal 48(no. 1, March):91-101.

Gentry, William M., and Alison P. Hagy (1996). "The Distributional Effects of the Tax Treatment of Child Care Expenses." In Empirical Foundations of Household Taxation, Martin Feldstein and James M. Poterba (eds.). Chicago: University of Chicago Press.

Liebman, Jeffrey B. (1998). "The Impact of the Earned Income Tax Credit on Incentives and Income Distribution." In Tax Policy and the Economy, James M. Poterba (ed.), vol. 12. Cambridge, MA: MTT Press, National Bureau of Economic Research.

McIntyre, Michael J., and C. Eugene Steuerle. (1996). "Federal Tax Reform: A Family Perspective." The Finance Project, Washington, DC. (July). 
Meyer, Bruce D., and Dan T. Rosenbaum (1999). "Welfare, the Earned Income Tax Credit, and the Labor Supply of Single Mothers." Mimeo. Northwestern University.

Mitrusi, Andrew and James Poterba (May 2000). "The Distribution of Payroll and Income Tax Burdens, 1979-1999," NBER Working Paper No. 7707.

Office of Management and Budget (2000). Analytical Perspectives. Budget of the United States. Washington, DC: U.S. Government Printing Office.

Steuerle, C. Eugene (1990). "Policy Watch: Tax Credits for Low-Income Workers with Children." Journal of Economic Perspectives 4(no. 3, Summer):201-212.

Reform for the Jation's Tax, Welfare, and Health Systems." Changing Dose of tic Priorities Policy Paper. Washington, DC: The Urban Institute.

Wheaton, Laura (1998). "Low-Income Families and the Marriage Tax." The Urban Institute. http://www.urban.org/family/marriage-tax.html. Accessed February $23,2000$.

Whittington, Leslie A., James Alm, and H. Elizabeth Peters (June 1990). "Fertility and the Personal Exemption: Implicit Pronatalist Policy in the United States." American Economic Review. Vol. 80 (3). p 545-56. 